\title{
Hypertension, Thrombosis, Kidney Failure, and Diabetes: Is COVID-19 an Endothelial Disease? A Comprehensive Evaluation of Clinical and Basic Evidence
}

\author{
Celestino Sardu ${ }^{1,2,+} \oplus$, Jessica Gambardella ${ }^{3,4, \dagger}$, Marco Bruno Morelli ${ }^{4,5, \dagger}$, Xujun Wang ${ }^{4}$, \\ Raffaele Marfella ${ }^{1}$ and Gaetano Santulli ${ }^{3,4,5, * \text { (D) }}$ \\ 1 Department of Advanced Medical and Surgical Sciences, University of Campania "Luigi Vanvitelli", \\ 80100 Naples, Italy; drsarducele@gmail.com (C.S.); raffaele.marfella@unicampania.it (R.M.) \\ 2 Department of Medical Sciences, International University of Health and Medical Sciences "Saint Camillus", \\ 00131 Rome, Italy \\ 3 Department of Advanced Biomedical Sciences, International Translational Research and Medical Education \\ Academic Research Unit (ITME), “Federico II” University, 80131 Naples, Italy; \\ jessica.gambardella@einsteinmed.org \\ 4 Department of Medicine, Division of Cardiology, Albert Einstein College of Medicine, Wilf Family \\ Cardiovascular Research Institute, New York, NY 10461, USA; marco.morelli@einstein.yu.edu (M.B.M.); \\ xujun.wang@einsteinmed.org (X.W.) \\ 5 Department of Molecular Pharmacology, Fleischer Institute for Diabetes and Metabolism (FIDAM), \\ Montefiore University Hospital, New York, NY 10461, USA \\ * Correspondence: gaetano.santulli@einsteinmed.org \\ + These authors equally contributed to this work.
}

Received: 12 April 2020; Accepted: 4 May 2020; Published: 11 May 2020

\begin{abstract}
The symptoms most commonly reported by patients affected by coronavirus disease (COVID-19) include cough, fever, and shortness of breath. However, other major events usually observed in COVID-19 patients (e.g., high blood pressure, arterial and venous thromboembolism, kidney disease, neurologic disorders, and diabetes mellitus) indicate that the virus is targeting the endothelium, one of the largest organs in the human body. Herein, we report a systematic and comprehensive evaluation of both clinical and preclinical evidence supporting the hypothesis that the endothelium is a key target organ in COVID-19, providing a mechanistic rationale behind its systemic manifestations.
\end{abstract}

Keywords: ACE2, acute kidney injury; blood pressure; catepsin; coronavirus; COVID; cytokine storm; endothelium; heparin; Kawasaki disease

\section{Introduction}

Coronavirus disease (COVID-19) represents a public health crisis of global proportions [1]. Caused by the severe acute respiratory syndrome corona virus 2 (SARS-CoV-2), COVID-19 was first announced in December 2019 in Wuhan, the capital of China's Hubei province [2,3].

The symptoms most commonly reported include cough, fever, and shortness of breath. The pathophysiology of the disease explains why respiratory symptoms are so common: indeed, the virus accesses host cells via the protein angiotensin-converting enzyme 2 (ACE2) [4,5], which is very abundant in the lungs [6].

Nevertheless, ACE2 is also expressed by endothelial cells $[7,8]$, and other major clinical events usually observed in COVID-19 patients (e.g., high blood pressure [9-13], thrombosis [14-16] kidney 
disease $[17,18]$, pulmonary embolism $[19,20]$, cerebrovascular and neurologic disorders [21,22]) indicate that the virus is targeting the endothelium [23], one of the largest organs in the human body [24-26]. The cases of Kawasaki disease reported in young COVID-19 patients [27] support our view of a systemic vasculitis caused by SARS-CoV-2.

\section{Pathogenesis of COVID-19}

To access host cells, SARS-CoV-2 uses a surface glycoprotein (peplomer) known as spike; ACE2 has been shown to be a co-receptor for coronavirus entry [28-30]. Therefore, the density of ACE2 in each tissue may correlate with the severity of the disease in that tissue [31-36]. Other receptors on the surface of human cells have been suggested to mediate the entry of SARS-CoV-2 [5], including transmembrane serine protease 2 (TMPRSS2) [37,38], sialic acid receptors [39,40], and extracellular matrix metalloproteinase inducer (CD147, also known as basigin) [41]. Additionally, catepsin B and L have been shown to be critical entry factors in the pathogenesis of COVID-19 [38,42].

Intriguingly, all of these factors involved in the entry of SARS-CoV-2 in the host cell are known to be expressed by endothelial cells [43-49] (Figure 1).

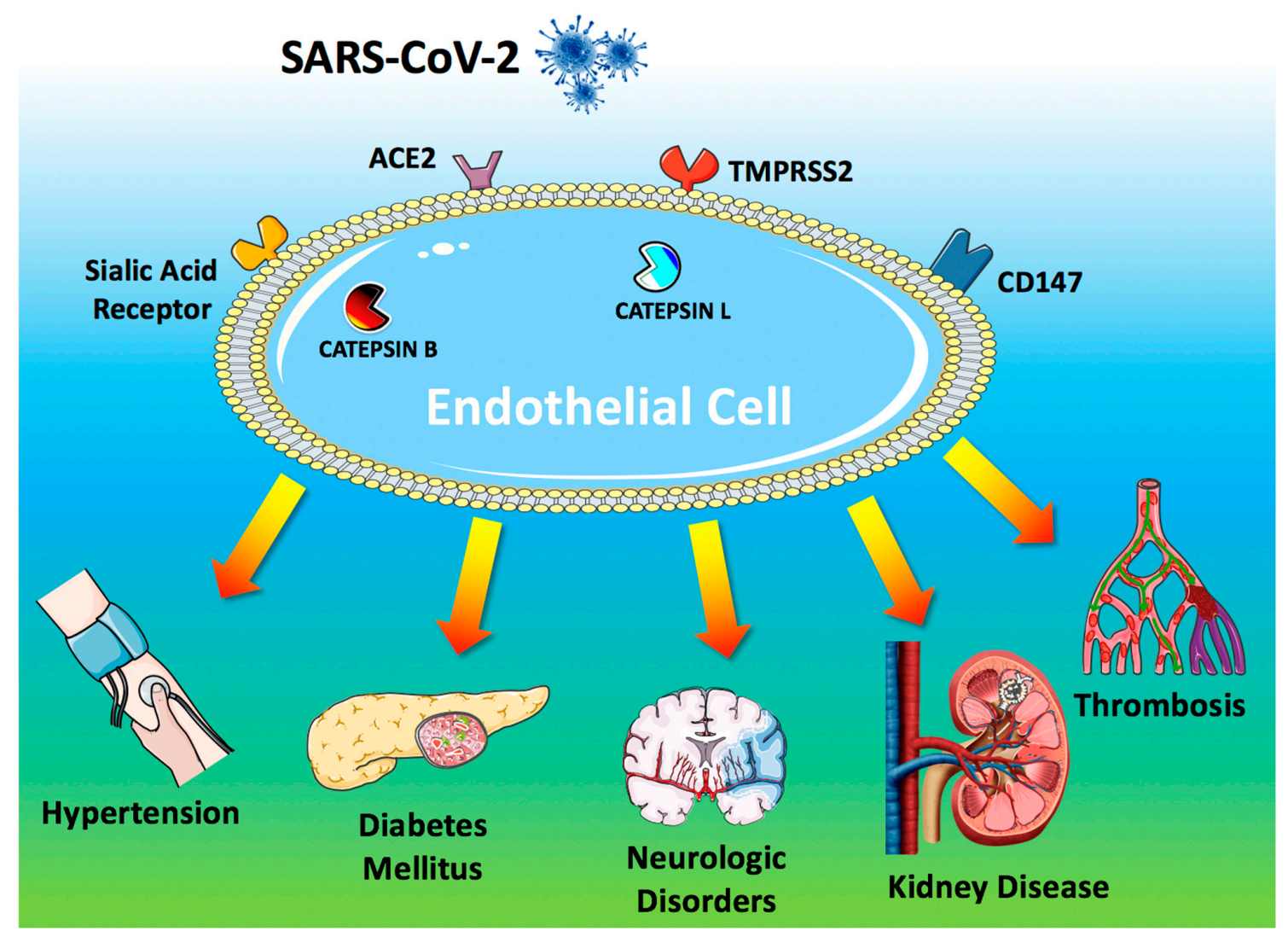

Figure 1. Endothelial dysfunction is a major determinant of COVID-19. The SARS-CoV-2 coronavirus accesses host cells via the binding of its spike glycoprotein to angiotensin-converting enzyme 2 (ACE2), sialic acid receptor, transmembrane serine protease 2 (TMPRSS2), and extracellular matrix metalloproteinase inducer (CD147); catepsin B and L also participate in virus entry. All of these factors are expressed in endothelial cells. Endothelial dysfunction is a common feature of the clinical manifestations observed in COVID-19 patients. All of the drugs proposed as a potential therapeutic strategy to treat COVID-19 patients have been shown to improve endothelial function, including tocilizumab, colchicine, chloroquine/hydroxychloroquine, azithromycin, and famotidine (see text for details and references). 
ACE2 remains the most studied of these receptors [34,50-54]: for instance, its genetic inactivation has been shown to cause severe lung injury in H5N1-challenged mice [55], whereas administration of recombinant human ACE2 ameliorates H5N1 virus-induced lung injury in mice [55].

ACE2 is currently at the center of a heated debate among physicians [56-59], and there are concerns that medical management of hypertension, including the use of inhibitors of the renin-angiotensinaldosterone system (RAAS), may contribute to the adverse health outcomes observed [34,60,61]; TMPRSS2 binds the viral spike glycoprotein [37]; recent structural assays have suggested that coronaviruses can bind sialic acid receptors [39]; CD147 has been shown to be essential for the entry of cytomegalovirus into endothelial cells [46]; both catepsin B [47] and L [49] are present in endothelial cells (Figure 1).

The endothelium prevents blood clotting by providing an antithrombotic surface, maintained by heparan sulphate present in the matrix surrounding the cells $[62,63]$, by the expression of tissue factor inhibitor [64], thrombomodulin [65], and by the production of tissue-type plasminogen activator that promotes fibrinolysis $[66,67]$.

Endothelial dysfunction refers to a systemic condition in which the endothelium loses its physiological properties, including the tendency to promote vasodilation, fibrinolysis, and anti-aggregation [68-72]; moreover, endothelial dysfunction appears to be a consistent finding in patients with diabetes $[69,73-78]$. Here we will discuss clinical and preclinical findings supporting our hypothesis [79] that COVID-19 impairs endothelial function (Figure 1).

\section{Hypertension and COVID-19}

Several investigators have called attention to the potential over-representation of hypertension among patients with COVID-19 [13,80-82]. Moreover, hypertension appears to track closely with advancing age, which is emerging as one of the strongest predictors of COVID-19-related death [14,83]. Specifically, observational trials and retrospectives studies conducted near Wuhan area have actually shown that hypertension is the most common co-morbidity observed in patients affected by COVID-19, ranging from $15 \%$ to over $30 \%$ [14,84-87].

One of the largest studies has been conducted by Guan et al. between December 11, 2019, and January 29, 2020, providing data on 1099 hospitalized patients and outpatients with laboratoryconfirmed COVID-19 infection [84]; in this cohort, $165(\sim 15 \%)$ had high blood pressure [84]. The authors also evaluated the severity of disease, and the composite outcome of intensive care unit (ICU) admission, mechanical ventilation and death, concluding that $23.7 \%$ of hypertensive patients had disease severity (vs. $13.4 \%$ of normotensive subjects), and that $35.8 \%$ (vs. $13.7 \%$ ) reached the composite endpoint of ICU admission, mechanical ventilation and death [84].

The high rate of hypertensive patients with COVID-19 was later confirmed in a prospective analysis on 41 patients admitted to hospital in Wuhan [85] as well as in a large study conducted on 138 hospitalized patients with confirmed COVID-19 infection [86]. In the latter report, the rate of hypertension was $31.2 \%$, and $58.3 \%$ of hypertensive patients with COVID-19 infection were admitted to ICU compared to $21.6 \%$ of individuals with normal blood pressure [86], evidencing the hypertensive state as a common co-morbidity and cause of ICU admission in COVID-19 patients [86].

Similarly, among 191 COVID-19 patients from Jinyintan Hospital and Wuhan Pulmonary Hospital, $58(30 \%)$ had hypertension, and $26(48 \%)$ did not survive COVID-19, whereas $32(23 \%)$ were survivors [14]. The $30 \%$ rate of hypertensive patients was further confirmed in an analysis based on the severity of COVID-19 conducted on 140 patients in Wuhan: 58 patients were classified as severe vs. 82 patients classified as not severe: hypertensive patients represented $37.9 \%$ of severe vs. $24.4 \%$ of not severe COVID-19 patients [87]. In a cohort of 1590 patients from 575 hospitals, underlying hypertension was independently associated with severe COVID-19 (hazard ratio 1.58, 95\% CI: 1.07-2.32) [13]. Overall, these findings confirm a dual aspect of hypertension during COVID-19 pandemic: first, hypertension is the most common co-morbidity observed in COVID-19 patients; second, hypertension is evidenced in patients with worse prognosis and higher rate of death. 
These studies also raise numerous questions regarding the association between hypertension and COVID-19. Indeed, hypertension is known to be one of most common diseases and co-morbidities worldwide, considered a silent killer for the worldwide population [88]. We speculate that the higher rate of hypertension and the worse prognosis in patients with COVID-19 infection could be seen as the spy of a cause-effect mechanism, more than as a casual pre-existing association between these two different diseases.

\section{ACE2 and Anti-Hypertensive Drugs: What Do We Know?}

ACE inhibitors (ACEi) and angiotensin II receptor blockers (ARB) represent very effective strategies for the treatment of hypertension [88]. These drugs reduce the effects of renin-angiotensin axis by inhibiting ACE (ACEi) or by blocking the angiotensin receptors (ARB), as shown in Figure 2. A growing question for the scientific community and physicians is to understand whether ACEi/ARB could affect the prognosis of hypertensive COVID-19 patients [34,89-91].

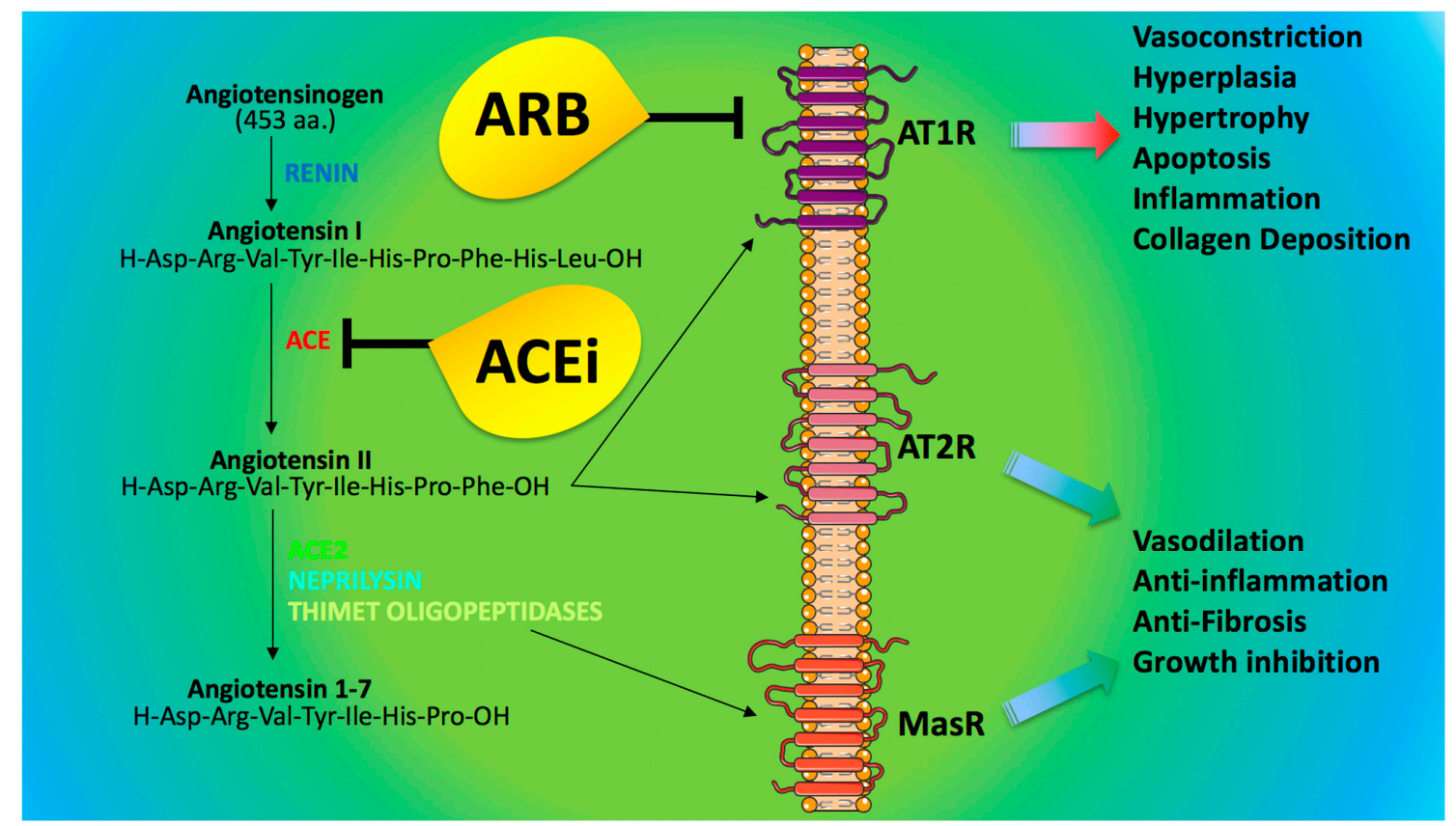

Figure 2. Angiotensin-converting enzyme inhibitors (ACEi) and blockers of the angiotensin receptor 1 (ARB). Angiotensin II and Angiotensin 1-7 binds heptahelical receptors; namely, angiotensin II can activate AT1R (type 1 angiotensin II receptor) and AT2R (type 2 angiotensin II receptor), whereas angiotensin 1-7 binds the Mas Receptor (MasR). The actions mediated by these receptors are depicted in the figure.

The exact role of ACEi/ARB in the control of ACE2 molecular pathways is controversial: indeed, preclinical studies evidenced that the selective blockade of either angiotensin II synthesis or activity in rats induces increases in ACE2 gene expression and activity [92-96]; similarly, treating infarcted rats with ARB increased plasma concentration of angiotensin 1-7 and ACE2 [97]. In mice, ARB treatment augmented ACE2 mRNA and protein levels [98,99] and prevented the decrease in ACE2 protein levels induced by Angiotensin II [100]. Equally important, mineralocorticoid receptor blockers prevented aldosterone-induced reduction in cardiac ACE2 mRNA expression in rat cardiomyocytes [101] and increased ACE2 expression and activity in murine hearts and in monocyte-derived macrophages obtained from ten patients with heart failure [102].

Nevertheless, there is no clinical evidence that ACEi could directly affect molecular pathways linked to ACE2 activity. For instance, urinary ACE2 levels were reported to be higher in patients treated with olmesartan vs. untreated controls, but this finding was not observed in patients treated 
with other ARB or enalapril [103]; instead, another study reported no difference in ACE2 activity in patients who were taking ACEi or ARB vs. untreated patients [89]. Of note, ACE2, which functions as a carboxypeptidase [104] is not inhibited by clinically prescribed ACEi.

In particular, ACE2 acts to counterbalance the effect of ACE [105]; indeed, whereas ACE generates angiotensin II from angiotensin I, ACE2 converts angiotensin II into an active heptapeptide (angiotensin 1-7), which binds the Mas receptor (MasR), triggering vasodilative, anti-oxidant, and anti-inflammatory properties [106-109] (Figure 2).

Some media sources have recently called for the discontinuation of ACEi and ARB, both prophylactically and in the context of suspected COVID-19 [110]. However, several associations have recommended not to suspend these therapies [61,111-114], and these recommendations have been confirmed by three recent studies: the first one performed on 362 hypertensive patients showed that ACEIs/ARBs are not associated with the severity or mortality of COVID-19 [91]; the second one verified the effects of ACEI/ARB on 1128 hypertensive COVID-19 patients, showing that the use of ACEI/ARB was associated with lower risk of all-cause mortality compared with ACEI/ARB non-users [115]; the third one demonstrated that without increasing the risk for SARS-CoV-2 infection, ACEI/ARB outcompeted other antihypertensive drugs in reducing inflammatory markers like C-reactive protein and procalcitonin levels in COVID-19 patients with preexisting hypertension [116]. Consistent with these findings, three observational studies performed in different populations and with different designs [117-119] (published in the same issue of the New England Journal of Medicine), arrived at the consistent message that the continued use of ACEI/ARB is unlikely to be harmful in COVID-19 patients. Notably, in one of these studies [117], the use of either ACEI or statins-two classes of drugs that are known to ameliorate endothelial function [120-123] — was found to be associated with a lower risk of in-hospital death than non-use.

The binding of the SARS-CoV-2 spike protein to ACE2 has been suggested to cause the down-regulation of ACE2 from the cell membrane [124]. Consequently, ACE2 down-regulation could lead to a loss of protective effects exerted by ACEi/ARB in humans [125]. Such down-regulation of ACE2 is an attractive research field [95,126-128]. Indeed, it could be a valid therapeutic target to ameliorate response and clinical prognosis in hypertensive patients affected by COVID-19. Moreover, some investigators proposed the restoration of ACE2 by administration of recombinant ACE2 to reverse the lung-injury process during viral infections [4]. Actually, these effects are being investigated in ongoing clinical trials (ClinicalTrials.gov NCT04287686), alongside the use of losartan as first therapy for COVID-19 in hospitalized (NCT04312009) or not hospitalized patients (NCT04311177). A major role in the pathogenesis of (as well as in the clinical response to) COVID-19 could also be played by ACE2 polymorphisms, which are relatively under-investigated if compared to ACE $[129,130]$.

Finally, we have to consider the higher rate of cardiac injury and adverse outcomes in hypertensive patients during the COVID-19 pandemic [131-133]. Therefore, ACEi/ARB chronic therapy should not be discontinued in hypertensive patients with COVID-19. Indeed, the loss of their pneumo- and cardioprotective effects could be detrimental [88]. In addition, in the absence of adequate follow-up visits, switching from ACEi/ARB to another anti-hypertensive therapy could cause a suboptimal control of blood pressure.

Thus, as suggested by several medical associations [110], in the absence of definitive clinical studies and without clear evidence, hypertensive patients should avoid discontinuation and/or therapeutic switching during COVID-19 infection.

Another noteworthy feature of COVID-19 for cardiologists is the significant decrease in the rates of hospital admissions for acute coronary syndromes which has been reported both in Italy [134] and US [135] during the COVID-19 outbreak, and despite being initially attributed to reduced air pollution, better adherence to treatment, or absence of occupational stress during lockdown, this phenomenon seems to be most likely due to the fear of going to the hospital and/or seeking medical attention during a pandemic. Unfortunately, the current decline in hospitalization for acute coronary syndromes will trigger an increase in cases of heart failure in the near future. 


\section{Kidney Disease in COVID-19}

Acute kidney injury (AKI) has been reported in $>20 \%$ of critically ill or deceased COVID-19 patients, a percentage that is consistent in studies from China [136], Italy [137] and United States [10]. It is important to note that AKI, proteinuria, and hematuria have been independently associated with a higher risk of death in COVID-19 patients [138]. Furthermore, in a meta-analysis including 1389 COVID-19 patients [139], the prevalence of underlying chronic kidney disease was significantly more frequent among those with a severe COVID-19 disease (3.3\% vs. $0.4 \%$; odds ratio $3.03,95 \%$ CI: 1.09-8.47).

According to immunohistochemistry assays [140], ACE2 seems not to be expressed in renal endothelial cells; however, a study based on single-cell analysis has confirmed the expression of ACE2 and TMPRSS2 in human renal endothelial cells [141], and most recently the presence of viral particles was confirmed by electron microscopy in endothelial cells of the glomerular capillary loops of a COVID-19 patient [142]. Besides, endothelial damage was a common finding in renal histopathological analyses of 26 COVID-19 patients, in the absence of interstitial inflammatory infiltrates [143].

\section{Diabetes and COVID-19}

Diabetes mellitus is a frequent co-morbidity and a cause of worse prognosis in COVID-19 patients [12,144-148]. Indeed, evaluating pneumonia cases of unknown causes reported in Wuhan and in patients with history of exposure to Huanan seafood market before Jan 1, 2020, 20\% had diabetes [85]. Similarly, among 1099 COVID-19 patients analyzed by Guan and colleagues, $7.4 \%$ had diabetes: this percentage goes up to $16.2 \%$ among patients with severe disease (vs. $5.7 \%$ in patients with non-severe disease) [84]; furthermore, $35.8 \%$ of patients experiencing the composite endpoint of ICU admission, mechanical ventilation and death, had diabetes (vs. $13.7 \%$ of patients that did not experience such endpoint) [84]. Data from Italy show that more than two-thirds of COVID-19 patients that did not survive had diabetes [149]. In summary, diabetes is a frequent co-morbidity, a risk factor, and an independent prognostic factor in COVID-19 patients. A strong evidence of the negative effects of diabetes in COVID-19 patients is also corroborated by two meta-analyses [150,151].

The worse prognosis in patients with diabetes and COVID-19 could be attributed to the fact that the pneumonia evolves towards clinical stages more refractory to medical therapies, oxygen administration and mechanical ventilation, with necessity of ICU care. These data have been investigated in a previous study conducted in patients with SARS [152], in which the relationship between a known history of diabetes and fasting plasma glucose (FPG) levels with death and morbidity rate was assessed, showing that the percentage of patients with diabetes was significantly higher in deceased vs. survivors $(21.5 \%$ vs. $3.9 \%, p<0.01)$ [152]. Moreover, diabetic subjects with hypoxemia $\left(\mathrm{SaO}_{2}<93 \%\right)$ had higher FPG levels and FPG was independently associated with an increased hazard ratio of mortality $(1.1,95 \% \mathrm{CI}$ : 1.0-1.1) and hypoxia (1.1, 95\% CI: 1.0-1.1) after controlling for age and gender [152]; the authors concluded that both diabetes (3.0, 95\% CI: $1.4-6.3)$ and FPG $>$ or $=7.0 \mathrm{mmol} / \mathrm{l}(3.3,95 \%$ CI: $1.4-7.7)$ were independent predictors of death [152].

In COVID-19 patients, the incidence of diabetes is two times higher in ICU/severe vs. non-ICU/severe cases [151]. Indeed, the diagnosis of diabetes in a cohort of patients with COVID-19 infection evidenced a sub-group of patients with a 2.26-fold higher risk of experiencing adverse disease outcome analyses [150]. Additionally, patients with obesity and/or glucose intolerance seem to be particularly vulnerable to COVID-19 [10,148,153,154]. Unfortunately, no data are hitherto available on anti-diabetic medications and glucose homeostasis in COVID-19 patients. This aspect is really limiting, because diabetes and altered glucose homeostasis during a condition of severe pneumonia with SARS are reported as main factors of worse prognosis and death [152]. COVID-19 could also induce new onset diabetes, by augmenting insulin resistance and/or by a direct action [155] on the islets of Langerhans; supporting this view, previous studies have shown that ACE2 can be a therapeutic target to ameliorate microcirculation in the islets [156], and ACE2 is known to be expressed by pancreatic beta cells [157-162]. 
Moreover, frequent cases of ketoacidosis in COVID-19 patients have been reported [163]. Therefore, the investigation of anti-diabetic medications and glucose homeostasis could be harnessed to evaluate patients with higher risk of experiencing worse prognosis and death by COVID-19. We speculate that the amelioration of glucose homeostasis in diabetic COVID-19 patients by specific hypoglycemic drugs could result in the amelioration of clinical outcomes with death reduction. However, these data are not reported in trials on COVID-19, and they need to be investigated in further studies [164].

\section{Thromboembolism and COVID-19}

Patients with COVID19 often show clotting disorders, with organ dysfunction and coagulopathy, resulting in higher mortality $[15,165,166]$. Critical data came from the analysis of coagulation tests including prothrombin time (PT), activated partial thromboplastin time (APTT), antithrombin activity (AT), fibrinogen, fibrin degradation product (FDP), and D-dimer, in samples collected on admission and during the hospital stay of COVID-19 patients [167]. Non-survivors had significantly higher D-dimer and FDP levels, and longer PT vs. survivors on admission [167]. Moreover, significant reduction and lowering of fibrinogen and AT levels were observed in non-survivors during late stages of hospitalization, which is compatible with a clinical diagnosis of disseminated intravascular coagulation (DIC) $[167,168]$. Specifically, among 191 COVID-19 patients seen at two hospitals in Wuhan, D-dimer levels over $1 \mu \mathrm{g} / \mathrm{L}$ at admission predicted an 18 -fold increase in odds of dying before discharge [14]. Of note, when DIC is caused by a systemic infection, it features an acute systemic over-inflammatory response, strictly linked to endothelial dysfunction [169].

Most recently a case of a COVID-19 patient with an increase of Factor VIII clotting activity and a massive elevation of von Willebrand Factor (vWF) has been reported [170], further supporting our theory: indeed, vWF can be seen as a marker of endothelial damage, since it is normally stored in Weibel-Palade bodies within endothelial cells [171]. Equally important, angiotensin II level in the plasma of COVID-19 patients was markedly elevated and linearly associated to viral load and lung injury [172]; notably, angiotensin II is known to increase microvascular permeability [173,174], to induce the transcription of tissue factor in endothelial cells [175-177], and to activate platelets [178-180]. Additionally, angiotensin II can trigger the release of several components of the complement system from endothelial cells [181-187], further corroborating the key role of endothelium in the pathogenesis of venous and arterial thrombosis in COVID-19 patients [188,189].

A dysregulated immune response, as observed in COVID-19, especially in the late stages of the disease, plays a decisive role in endothelial dysfunction and thrombosis [190,191], and microvascular permeability is crucial in viral infections [192]. Indeed, pulmonary endothelium represent a fundamental barrier between the blood and interstitium and have vital regulatory functions; specifically, endothelial cells represent one-third of the cell population of the lung [193], and pulmonary endothelial damage is considered the hallmark of acute respiratory distress syndrome (ARDS) [194]. Animal models of coronavirus-induced severe ARDS have shown that reduced ACE2 activity and loss of ACE2 in the lungs is mirrored by enhanced vascular permeability, and exacerbated pulmonary edema [108]. The functional role of endothelium in pulmonary disease is also suggested by previous reports [195,196]; for instance, the H3N2 influenza virus has been shown to infect endothelial cells in vitro and to trigger endothelial cell apoptosis, which is known to enhance platelet adhesion [197]: endothelial cell death would cause exposure of the extracellular matrix to circulating blood, favoring platelet binding; similarly, the endothelium has been shown to contribute to the development of severe disease during H5N1 influenza infection [198].

Deep vein thrombosis and/or pulmonary embolism have been previously described in patients with SARS [199-202] and cases of thrombosis complicating influenza-associated pneumonia have also been reported [203-205]. Excessive activation of the immune system in response to pathogens can lead to pathological inflammatory consequences. In the case of highly virulent 1918 and avian H5N1 influenza virus infections, the recruitment of inflammatory leukocytes followed by excessive cytokine responses is considered to be the key contributor to morbidity and mortality of the infection [206,207]. 
Cytokine storm syndromes (CSS) are a group of disorders representing a variety of inflammatory etiologies with the final result of overwhelming systemic inflammation, hemodynamic instability, multiple organ dysfunction, and potentially death [208,209]. Specifically, macrophage activation syndrome [210] and hemophagocytic lymphohistiocytosis (HLH) [211] represent two clinically similar CSS with an unknown degree of etiopathogenic overlap [208]. The interaction between endothelial and immune cells could play a crucial role in COVID-19, especially in severe cases and in the late stages of the disease [212]. For instance, the cytokine storm might lead to an abrupt deterioration of the inflammatory response and hyper-coagulation; the increased vulnerability of patients with cardiovascular diseases and/or diabetes might therefore simply reflect the impact of the underlying chronic inflammation and its response during SARS-CoV-2 infection. If this is the case, endothelial alterations could just be seen as an epiphenomenon.

However, according to numerous investigators, the inflammatory response observed in COVID-19 patients can be considered mild if compared to the one observed in typical ARDS and in cytokine-release syndrome [212-215]: indeed, in ARDS patients, levels of interleukin-1 $\beta$ and interleukin- 6 have been shown to be 10 to 60 fold higher than in COVID-19 [216,217]. Therefore, other mechanisms have to be involved in order to explain the systemic manifestations reported in COVID-19 patients, and endothelial cells, known orchestrators of cytokine amplification during viral infections [218], seem to be one of the best candidates in this sense. Further supporting our view, catecholamines are considered an essential component of the cytokine release syndrome [215] and we have demonstrated that endothelial cells are able to synthetize and release catecholamines [219].

Acute pulmonary embolism, reported in COVID-19 patients [20,220-222], has been shown to be a cause of clinical deterioration in viral pneumonias [205,223]. Endothelial dysfunction is known to be a key determinant in hypertension, thrombosis, and DIC [72,224-227]. Henceforth, it is important to select COVID-19 patients at higher risk of pulmonary embolism, and practice computed tomography pulmonary angiography for the diagnosis of pulmonary thromboembolism especially in case of significant increase of D-dimer values. Anticoagulation could be a necessary therapy to control and reduce pro-thrombotic events, as well as to prevent pulmonary embolism [228].

\section{Anticoagulation as a Key Therapy for COVID-19}

The clinical course of COVID-19 consists of two main phases: viral infection and immune/ inflammatory response (Figure 3), which require distinct therapeutic approaches. Strikingly, several drugs suggested as a potential therapeutic strategy for COVID-19 [229-231] have been shown to ameliorate endothelial function, including interleukin 6 (IL-6) receptor antagonists (e.g., tocilizumab [232]), colchicine [233], azithromycin [234], and famotidine [235].

Even the antimalaric agents chloroquine and hydroxychloroquine, initially proposed as a therapy for COVID-19 based on anecdotal data $[229,236]$, have been shown to improve endothelial function $[237,238]$. If our theory is correct [239], other drugs that might be effective in treating COVID-19 patients through their beneficial effects on endothelial cells include $\alpha 1$ adrenergic receptor blockers (e.g., doxazosin) [240], modulators of Sigma receptors [241-243], metformin [244], indomethacin [245], and endothelin receptor antagonists (e.g., bosentan) [246]. However, data from randomized trials confirming the actual efficacy of these drugs are not (yet) available.

As discussed before, COVID-19 infection could cause endothelial dysfunction and a hypercoagulation state. This condition is aggravated by hypoxia, which augments thrombosis by both increasing blood viscosity and hypoxia-inducible transcription factor-dependent signaling pathway [247]. Consequently, these phenomena could result in pulmonary embolism with occlusion and micro-thrombosis in pulmonary small vessels, as observed in critical COVID-19 patients [248]. Apart from cases of pulmonary embolism, COVID-19 can cause a sepsis-associated DIC, which is defined as "sepsis-induced coagulopathy" (SIC) [169]. Thus, there is an increasing interest in anticoagulant therapy to treat COVID-19 [249]. 


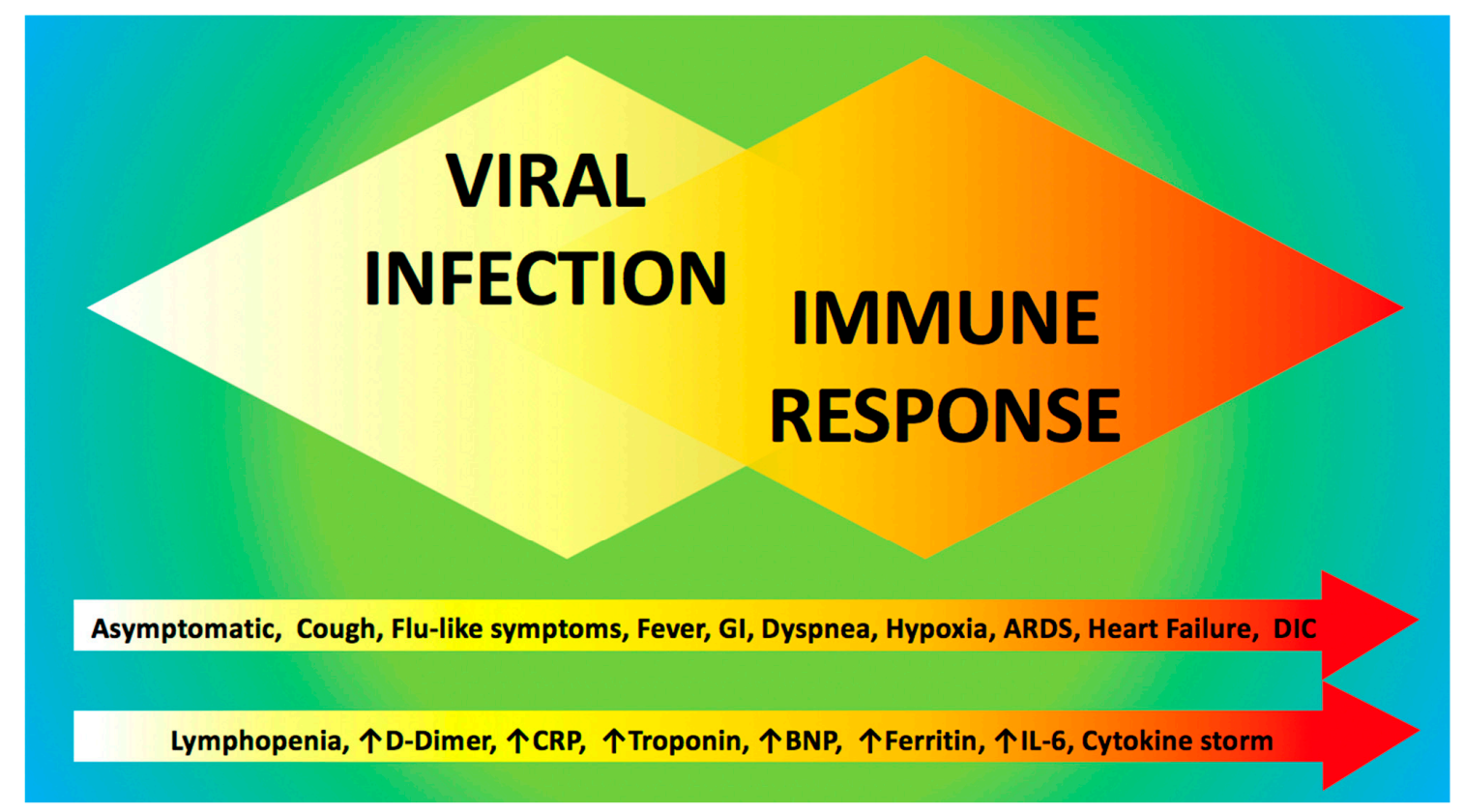

Figure 3. Clinical course of COVID-19 patients. Two main overlapping phases constitute the key pathogenic events in COVID-19: the acute phase represented by viral infection, followed by the immune/inflammatory response. Common clinical and laboratory findings are reported within the arrows at the bottom of the figure.

In a retrospective analysis conducted at Tongji Hospital of Huazhong University of Science and Technology in Wuhan, the authors examined 449 patients affected by severe COVID-19 [228]. The diagnosis of severe COVID-19 disease was made by evidence of respiratory rate $\geq 30$ breaths/min, arterial oxygen saturation $\leq 93 \%$ at rest and $\mathrm{PaO}_{2} / \mathrm{FiO}_{2} \leq 300 \mathrm{mmHg}$ [228]. In these patients, they reviewed and compared the parameters of coagulation tests and clinical characteristics between survivors and non-survivors to evaluate the effects of heparin therapy [228]: 94 patients received low molecular weight heparin (LMWH, 40-60 mg enoxaparin/day) and 5 received unfractionated heparin (UFH, 10000-15000 U/day), without other anti-coagulants [228]. Heparin therapy significantly reduced mortality in patients with SIC score $\geq 4(40.0 \%$ vs. $64.2 \%, p<0.05)$, but not in those with SIC score $<4(29.0 \%$ vs. $22.6 \%, p>0.05)$ [228]. D-dimer, PT, and age were positively, while platelet count was negatively, correlated with 28-day mortality [228]. In addition, stratifying by D-dimer values the study population, the authors reported in heparin non-users a rise of mortality linked to the rising D-dimer, and $20 \%$ reduction of mortality for patients under heparin with D-dimer exceeding $3.0 \mu \mathrm{g} / \mathrm{mL}$ [228]. Therefore, heparin treatment appears to be associated with better prognosis in severe COVID-19 patients with coagulopathy. The beneficial effects of heparin-based therapies are also supported by the structural analogies between heparin and heparan-sulphate, which according to some investigators may confer heparin with antiviral properties [250-254]. In absence of contraindications, we suggest the use of enoxaparin $40 \mathrm{mg} /$ day in all COVID-19 patients, to be raised up to $1 \mathrm{mg} / \mathrm{kg}$ every $12 \mathrm{~h}$ in case of D-dimer $>3.0 \mu \mathrm{g} / \mathrm{mL}$; apixaban $(5 \mathrm{mg}$ every $12 \mathrm{~h}$ ) could represent a useful alternative.

Of course, the full clinical evaluation of patients with COVID-19 infection cannot leave aside the analysis of laboratory and imaging data. We believe that PT/PTT, fibrinogen, and D-Dimer should be monitored daily and anticoagulation therapy should be recommended for COVID-19 patients when the D-Dimer value is four times higher than the normal upper limit, except for patients with anticoagulant contraindications. The confirmed diagnosis of severe COVID-19 disease in patients with hypercoagulation and organ failure could evidence an early stage of sepsis-induced DIC. On the other hand, anticoagulant may not benefit unselected patients. Consequently, further prospective studies 
are needed to confirm these findings in COVID-19 patients, also testing other anti-aggregants and anti-coagulants (at different doses).

Author Contributions: Conceptualization, G.S.; data curation, C.S., J.G., M.B.M., X.W., R.M. and G.S. and S.R.; writing—original draft preparation, C.S., J.G. and G.S.; writing—review and editing, J.G., M.B.M. and G.S.; visualization, M.B.M. and G.S.; supervision, G.S.; funding acquisition, G.S. and J.G. A preprint version of the manuscript was sent to preprints.org by on 9 April 2020: Preprints 2020, 2020040204 (doi:10.20944/preprints202004.0204.v1). All authors have read and agreed to the published version of the manuscript.

Funding: The Santulli's lab is supported in part by the NIH (R01-DK123259, R01-HL146691, R01-DK033823, and R00-DK107895 to G.S.) and by the American Heart Association (AHA-20POST35211151 to J.G.).

Conflicts of Interest: The authors declare no conflict of interest. The funders had no role in the design of the study; in the collection, analyses, or interpretation of data; in the writing of the manuscript, or in the decision to publish the paper.

\section{References}

1. Fauci, A.S.; Lane, H.C.; Redfield, R.R. Covid-19-Navigating the Uncharted. N. Engl. J. Med. 2020, 382, 1268-1269. [CrossRef] [PubMed]

2. Paules, C.I.; Marston, H.D.; Fauci, A.S. Coronavirus Infections-More Than Just the Common Cold. JAMA 2020, 323, 707. [CrossRef] [PubMed]

3. Hui, D.S.; Azhar, E.E.; Madani, T.A.; Ntoumi, F.; Kock, R.; Dar, O.; Ippolito, G.; McHugh, T.D.; Memish, Z.A.; Drosten, C.; et al. The continuing 2019-nCoV epidemic threat of novel coronaviruses to global health-The latest 2019 novel coronavirus outbreak in Wuhan, China. Int. J. Infect. Dis. 2020, 91, 264-266. [CrossRef] [PubMed]

4. Zhang, H.; Penninger, J.M.; Li, Y.; Zhong, N.; Slutsky, A.S. Angiotensin-converting enzyme 2 (ACE2) as a SARS-CoV-2 receptor: Molecular mechanisms and potential therapeutic target. Intensive Care Med. 2020, 46, 586-590. [CrossRef] [PubMed]

5. Zhou, P.; Yang, X.L.; Wang, X.G.; Hu, B.; Zhang, L.; Zhang, W.; Si, H.R.; Zhu, Y.; Li, B.; Huang, C.L.; et al. A pneumonia outbreak associated with a new coronavirus of probable bat origin. Nature 2020, 579, $270-273$. [CrossRef]

6. Hamming, I.; Timens, W.; Bulthuis, M.L.; Lely, A.T.; Navis, G.; van Goor, H. Tissue distribution of ACE2 protein, the functional receptor for SARS coronavirus. A first step in understanding SARS pathogenesis. J. Pathol. 2004, 203, 631-637. [CrossRef]

7. Lovren, F.; Pan, Y.; Quan, A.; Teoh, H.; Wang, G.; Shukla, P.C.; Levitt, K.S.; Oudit, G.Y.; Al-Omran, M.; Stewart, D.J.; et al. Angiotensin converting enzyme-2 confers endothelial protection and attenuates atherosclerosis. Am. J. Physiol. Circ. Physiol. 2008, 295, H1377-H1384. [CrossRef]

8. Sluimer, J.C.; Gasc, J.M.; Hamming, I.; van Goor, H.; Michaud, A.; van den Akker, L.H.; Jutten, B.; Cleutjens, J.; Bijnens, A.P.; Corvol, P.; et al. Angiotensin-converting enzyme 2 (ACE2) expression and activity in human carotid atherosclerotic lesions. J. Pathol. 2008, 215, 273-279. [CrossRef]

9. Schiffrin, E.L.; Flack, J.; Ito, S.; Muntner, P.; Webb, C. Hypertension and COVID-19. Am. J. Hypertens. 2020, 33, 33-373. [CrossRef]

10. Richardson, S.; Hirsch, J.S.; Narasimhan, M.; Crawford, J.M.; McGinn, T.; Davidson, K.W. The Northwell COVID-19 Research Consortium. Presenting Characteristics, Comorbidities, and Outcomes among 5700 Patients Hospitalized With COVID-19 in the New York City Area. JAMA 2020. [CrossRef]

11. Chen, T.; Wu, D.; Chen, H.; Yan, W.; Yang, D.; Chen, G.; Ma, K.; Xu, D.; Yu, H.; Wang, H.; et al. Clinical characteristics of 113 deceased patients with coronavirus disease 2019: Retrospective study. BMJ 2020, 368, m1091. [CrossRef] [PubMed]

12. Myers, L.C.; Parodi, S.M.; Escobar, G.J.; Liu, V.X. Characteristics of Hospitalized Adults With COVID-19 in an Integrated Health Care System in California. JAMA 2020. [CrossRef] [PubMed]

13. Guan, W.J.; Liang, W.H.; Zhao, Y.; Liang, H.R.; Chen, Z.S.; Li, Y.M.; Liu, X.Q.; Chen, R.C.; Tang, C.L.; Wang, T.; et al. Comorbidity and its impact on 1590 patients with Covid-19 in China: A Nationwide Analysis. Eur. Respir. J. 2020, 2000547. [CrossRef] [PubMed] 
14. Zhou, F.; Yu, T.; Du, R.; Fan, G.; Liu, Y.; Liu, Z.; Xiang, J.; Wang, Y.; Song, B.; Gu, X.; et al. Clinical course and risk factors for mortality of adult inpatients with COVID-19 in Wuhan, China: A retrospective cohort study. Lancet 2020, 395, 1054-1062. [CrossRef]

15. Bikdeli, B.; Madhavan, M.V.; Jimenez, D.; Chuich, T.; Dreyfus, I.; Driggin, E.; Nigoghossian, C.; Ageno, W.; Madjid, M.; Guo, Y.; et al. Lip GYH. COVID-19 and Thrombotic or Thromboembolic Disease: Implications for Prevention, Antithrombotic Therapy, and Follow-up. J. Am. Coll. Cardiol. 2020. [CrossRef]

16. Klok, F.A.; Kruip, M.; van der Meer, N.J.M.; Arbous, M.S.; Gommers, D.; Kant, K.M.; Kaptein, F.H.J.; van Paassen, J.; Stals, M.A.M.; Huisman, M.V.; et al. Incidence of thrombotic complications in critically ill ICU patients with COVID-19. Thromb. Res. 2020. [CrossRef]

17. Durvasula, R.; Wellington, T.; McNamara, E.; Watnick, S. COVID-19 and Kidney Failure in the Acute Care Setting: Our Experience From Seattle. Am. J. Kidney Dis. 2020. [CrossRef]

18. Ronco, C.; Reis, T. Kidney involvement in COVID-19 and rationale for extracorporeal therapies. Nat. Rev. Nephrol. 2020, 1-3. [CrossRef]

19. Rotzinger, D.C.; Beigelman-Aubry, C.; von Garnier, C.; Qanadli, S.D. Pulmonary embolism in patients with COVID-19: Time to change the paradigm of computed tomography. Thromb. Res. 2020, 190, 58-59. [CrossRef]

20. Poissy, J.; Goutay, J.; Caplan, M.; Parmentier, E.; Duburcq, T.; Lassalle, F.; Jeanpierre, E.; Rauch, A.; Labreuche, J.; Susen, S. Pulmonary Embolism in COVID-19 Patients: Awareness of an Increased Prevalence. Circulation 2020. [CrossRef]

21. Aggarwal, G.; Lippi, G.; Michael Henry, B. Cerebrovascular disease is associated with an increased disease severity in patients with Coronavirus Disease 2019 (COVID-19): A pooled analysis of published literature. Int. J. Stroke 2020, 1747493020921664. [CrossRef] [PubMed]

22. Mao, L.; Jin, H.; Wang, M.; Hu, Y.; Chen, S.; He, Q.; Chang, J.; Hong, C.; Zhou, Y.; Wang, D.; et al. Neurologic Manifestations of Hospitalized Patients With Coronavirus Disease 2019 in Wuhan, China. JAMA Neurol. 2020. [CrossRef] [PubMed]

23. Santulli, G.; Morelli, M.; Gambardella, J. Is Endothelial Dysfunction the Concealed Cornerstone of COVID-19? BMJ 2020, in press.

24. Cooke, J.P. The endothelium: A new target for therapy. Vasc. Med. 2000, 5, 49-53. [CrossRef] [PubMed]

25. Aird, W.C. Endothelium as an organ system. Crit. Care Med. 2004, 32, S271-S279. [CrossRef] [PubMed]

26. Inagami, T.; Naruse, M.; Hoover, R. Endothelium as an endocrine organ. Annu. Rev. Physiol. 1995, 57, 171-189. [CrossRef] [PubMed]

27. Riphagen, S.; Gomez, R.; Gonzalez-Martinez, C.; Wilkinson, N.; Theocharis, P. Hyperinflammatory shock in children during COVID-19 pandemic. Lancet 2020, in press. [CrossRef]

28. Letko, M.; Marzi, A.; Munster, V. Functional assessment of cell entry and receptor usage for SARS-CoV-2 and other lineage B betacoronaviruses. Nat. Microbiol. 2020, 5, 562-569. [CrossRef]

29. Wang, Q.; Zhang, Y.; Wu, L.; Niu, S.; Song, C.; Zhang, Z.; Lu, G.; Qiao, C.; Hu, Y.; Yuen, K.Y.; et al. Structural and Functional Basis of SARS-CoV-2 Entry by Using Human ACE2. Cell 2020. [CrossRef]

30. Guzzi, P.H.; Mercatelli, D.; Ceraolo, C.; Giorgi, F.M. Master Regulator Analysis of the SARS-CoV-2/Human Interactome. J. Clin. Med. 2020, 9, 982. [CrossRef]

31. Xu, H.; Zhong, L.; Deng, J.; Peng, J.; Dan, H.; Zeng, X.; Li, T.; Chen, Q. High expression of ACE2 receptor of 2019-nCoV on the epithelial cells of oral mucosa. Int. J. Oral Sci. 2020, 12, 8. [CrossRef] [PubMed]

32. Jia, H.P.; Look, D.C.; Shi, L.; Hickey, M.; Pewe, L.; Netland, J.; Farzan, M.; Wohlford-Lenane, C.; Perlman, S.; McCray, P.B., Jr. ACE2 receptor expression and severe acute respiratory syndrome coronavirus infection depend on differentiation of human airway epithelia. J. Virol. 2005, 79, 14614-14621. [CrossRef] [PubMed]

33. Perico, L.; Benigni, A.; Remuzzi, G. Should COVID-19 Concern Nephrologists? Why and to What Extent? The Emerging Impasse of Angiotensin Blockade. Nephron 2020, 1-9. [CrossRef] [PubMed]

34. Gheblawi, M.; Wang, K.; Viveiros, A.; Nguyen, Q.; Zhong, J.; Turner, A.T.; Raizada, M.K.; Grant, M.B.; Oudit, G.Y. Angiotensin Converting Enzyme 2: SARS-CoV-2 Receptor and Regulator of the Renin-Angiotensin System. Circ. Res. 2020, 126. [CrossRef] [PubMed]

35. Li, M.; Chen, L.; Zhang, J.; Xiong, C.; Li, X. The SARS-CoV-2 receptor ACE2 expression of maternal-fetal interface and fetal organs by single-cell transcriptome study. PLoS ONE 2020, 15, e0230295. [CrossRef]

36. Gallagher, T.M.; Buchmeier, M.J. Coronavirus spike proteins in viral entry and pathogenesis. Virology 2001, 279, 371-374. [CrossRef] 
37. Matsuyama, S.; Nao, N.; Shirato, K.; Kawase, M.; Saito, S.; Takayama, I.; Nagata, N.; Sekizuka, T.; Katoh, H.; Kato, F.; et al. Enhanced isolation of SARS-CoV-2 by TMPRSS2-expressing cells. Proc. Natl. Acad. Sci. USA 2020, 117, 7001-7003. [CrossRef]

38. Sungnak, W.; Huang, N.; Becavin, C.; Berg, M.; Queen, R.; Litvinukova, M.; Talavera-Lopez, C.; Maatz, H.; Reichart, D.; Sampaziotis, F.; et al. SARS-CoV-2 entry factors are highly expressed in nasal epithelial cells together with innate immune genes. Nat. Med. 2020. [CrossRef]

39. Tortorici, M.A.; Walls, A.C.; Lang, Y.; Wang, C.; Li, Z.; Koerhuis, D.; Boons, G.-J.; Bosch, B.-J.; Rey, F.A.; De Groot, R.J.; et al. Structural basis for human coronavirus attachment to sialic acid receptors. Nat. Struct. Mol. Biol. 2019, 26, 481-489. [CrossRef]

40. Hulswit, R.; Lang, Y.; Bakkers, M.J.G.; Li, W.; Li, Z.; Schouten, A.; Ophorst, B.; Van Kuppeveld, F.J.M.; Boons, G.-J.; Bosch, B.-J.; et al. Human coronaviruses OC43 and HKU1 bind to 9-O-acetylated sialic acids via a conserved receptor-binding site in spike protein domain A. Proc. Natl. Acad. Sci. USA 2019, 116, 2681-2690. [CrossRef]

41. Chen, Z.; Mi, L.; Xu, J.; Yu, J.; Wang, X.; Jiang, J.; Xing, J.; Shang, P.; Qian, A.; Li, Y.; et al. Function of $\mathrm{HAb18G/CD147} \mathrm{in} \mathrm{invasion} \mathrm{of} \mathrm{host} \mathrm{cells} \mathrm{by} \mathrm{severe} \mathrm{acute} \mathrm{respiratory} \mathrm{syndrome} \mathrm{coronavirus.} \mathrm{J.} \mathrm{Infect.} \mathrm{Dis.}$ 2005, 191, 755-760. [CrossRef] [PubMed]

42. Ou, X.; Liu, Y.; Lei, X.; Li, P.; Mi, D.; Ren, L.; Guo, L.; Guo, R.; Chen, T.; Hu, J.; et al. Characterization of spike glycoprotein of SARS-CoV-2 on virus entry and its immune cross-reactivity with SARS-CoV. Nat. Commun. 2020, 11, 1620. [CrossRef] [PubMed]

43. Yang, J.; Feng, X.; Zhou, Q.; Cheng, W.; Shang, C.; Han, P.; Lin, C.-H.; Chen, H.-S.V.; Quertermous, T.; Chang, C.-P. Pathological Ace2-to-Ace enzyme switch in the stressed heart is transcriptionally controlled by the endothelial Brg1-FoxM1 complex. Proc. Natl. Acad. Sci. USA 2016, 113, E5628-E5635. [CrossRef] [PubMed]

44. Aimes, R.; Zijlstra, A.; Hooper, J.; Ogbourne, S.; Sit, M.-L.; Fuchs, S.; Gotley, D.; Quigley, J.P.; Antalis, T. Endothelial cell serine proteases expressed during vascular morphogenesis and angiogenesis. Thromb. Haemost. 2003, 89, 561-572. [CrossRef] [PubMed]

45. Huang, D.T.-N.; Lu, C.-Y.; Chi, Y.; Li, W.-L.; Chang, L.-Y.; Lai, M.-J.; Chen, J.-S.; Hsu, W.-M.; Huang, L.-M. Adaptation of influenza A (H7N9) virus in primary human airway epithelial cells. Sci. Rep. 2017, 7, 11300. [CrossRef]

46. Vanarsdall, A.L.; Pritchard, S.R.; Wisner, T.W.; Liu, J.; Jardetzky, T.S.; Johnson, D.C. CD147 Promotes Entry of Pentamer-Expressing Human Cytomegalovirus into Epithelial and Endothelial Cells. mBio 2018, 9, e00781-18. [CrossRef]

47. Im, E.; Venkatakrishnan, A.; Kazlauskas, A. Cathepsin B regulates the intrinsic angiogenic threshold of endothelial cells. Mol. Biol. Cell. 2005, 16, 3488-3500. [CrossRef]

48. Platt, M.O.; Shockey, W.A. Endothelial cells and cathepsins: Biochemical and biomechanical regulation. Biochimie 2016, 122, 314-323. [CrossRef]

49. Cai, J.; Zhong, H.; Wu, J.; Chen, R.-F.; Yang, H.; Al-Abed, Y.; Li, Y.; Li, X.; Jiang, W.; Montenegro, M.F.; et al. Cathepsin L promotes Vascular Intimal Hyperplasia after Arterial Injury. Mol. Med. 2017, 23, 92-100. [CrossRef]

50. Rivellese, F.; Prediletto, E. ACE2 at the centre of COVID-19 from paucisymptomatic infections to severe pneumonia. Autoimmun. Rev. 2020, 102536. [CrossRef]

51. Touyz, R.M.; Li, H.; Delles, C. ACE2 the Janus-faced protein-From cardiovascular protection to severe acute respiratory syndrome-coronavirus and COVID-19. Clin. Sci. (Lond.) 2020, 134, 747-750. [CrossRef]

52. Leng, Z.; Zhu, R.; Hou, W.; Fengchun, Z.; Yangyang, Z.; Luchan, D.; Shan, G.; Meng, F.; Du, D.; Wang, S.; et al. Transplantation of ACE2(-) Mesenchymal Stem Cells Improves the Outcome of Patients with COVID-19 Pneumonia. Aging Dis. 2020, 11, 216-228. [CrossRef] [PubMed]

53. Brake, S.; Barnsley, K.; Lu, W.; McAlinden, K.; Eapen, M.S.; Sohal, S.S. Smoking Upregulates Angiotensin-Converting Enzyme-2 Receptor: A Potential Adhesion Site for Novel Coronavirus SARS-CoV-2 (Covid-19). J. Clin. Med. 2020, 9, 841. [CrossRef] [PubMed]

54. Jakovac, H. COVID-19-is the ACE2 just a foe? Am. J. Physiol. Cell. Mol. Physiol. 2020. [CrossRef] [PubMed]

55. Zou, Z.; Yan, Y.; Shu, Y.; Gao, R.; Sun, Y.; Li, X.; Ju, X.; Liang, Z.; Liu, Q.; Zhao, Y.; et al. Angiotensin-converting enzyme 2 protects from lethal avian influenza A H5N1 infections. Nat. Commun. 2014, 5, 3594. [CrossRef] [PubMed] 
56. Guo, J.; Huang, Z.; Lin, L.; Lv, J. Coronavirus Disease 2019 (COVID-19) and Cardiovascular Disease: A Viewpoint on the Potential Influence of Angiotensin-Converting Enzyme Inhibitors/Angiotensin Receptor Blockers on Onset and Severity of Severe Acute Respiratory Syndrome Coronavirus 2 Infection. J. Am. Heart Assoc. 2020, 9, e016219. [PubMed]

57. Mourad, J.-J.; Levy, B.I. Interaction between RAAS inhibitors and ACE2 in the context of COVID-19. Nat. Rev. Cardiol. 2020, 17, 313. [CrossRef]

58. South, A.M.; Diz, D.; Chappell, M.C. COVID-19, ACE2 and the Cardiovascular Consequences. Am. J. Physiol. Heart Circ. Physiol. 2020. [CrossRef]

59. Chen, L.; Li, X.; Chen, M.; Feng, Y.; Xiong, C. The ACE2 expression in human heart indicates new potential mechanism of heart injury among patients infected with SARS-CoV-2. Cardiovasc. Res. 2020, 116, 1097-1100. [CrossRef]

60. Sommerstein, R.; Kochen, M.M.; Messerli, F.H.; Grani, C. Coronavirus Disease 2019 (COVID-19): Do Angiotensin-Converting Enzyme Inhibitors/Angiotensin Receptor Blockers Have a Biphasic Effect? J. Am. Heart Assoc. 2020, 9, e016509. [CrossRef]

61. Danser, A.J.; Epstein, M.; Batlle, D. Renin-Angiotensin System Blockers and the COVID-19 Pandemic: At Present There Is No Evidence to Abandon Renin-Angiotensin System Blockers. Hypertension 2020, 12015082. [CrossRef] [PubMed]

62. Wang, M.; Hao, H.; Leeper, N.J.; Zhu, L. Thrombotic Regulation from the Endothelial Cell Perspectives. Arter. Thromb. Vasc. Biol. 2018, 38, e90-e95. [CrossRef] [PubMed]

63. Bernfield, M.; Götte, M.; Park, P.W.; Reizes, O.; Fitzgerald, M.L.; Lincecum, J.; Zako, M. Functions of cell surface heparan sulfate proteoglycans. Annu. Rev. Biochem. 1999, 68, 729-777. [CrossRef] [PubMed]

64. Mast, A.E. Tissue Factor Pathway Inhibitor: Multiple Anticoagulant Activities for a Single Protein. Arter. Thromb. Vasc. Biol. 2016, 36, 9-14. [CrossRef]

65. Martin, F.A.; Murphy, R.P.; Cummins, P.M. Thrombomodulin and the vascular endothelium: Insights into functional, regulatory, and therapeutic aspects. Am. J. Physiol. Circ. Physiol. 2013, 304, H1585-H1597. [CrossRef]

66. Oliver, J.; Webb, D.J.; Newby, D.E. Stimulated tissue plasminogen activator release as a marker of endothelial function in humans. Arter. Thromb. Vasc. Biol. 2005, 25, 2470-2479. [CrossRef]

67. Huber, D.; Cramer, E.M.; Kaufmann, J.E.; Meda, P.; Massé, J.-M.; Kruithof, E.K.O.; Vischer, U.M. Tissue-type plasminogen activator (t-PA) is stored in Weibel-Palade bodies in human endothelial cells both in vitro and in vivo. Blood 2002, 99, 3637-3645. [CrossRef]

68. Godo, S.; Shimokawa, H. Endothelial Functions. Arter. Thromb. Vasc Biol. 2017, 37, e108-e114. [CrossRef]

69. Vanhoutte, P.M.; Shimokawa, H.; Tang, E.H.; Feletou, M. Endothelial dysfunction and vascular disease. Acta Physiol. 2009, 196, 193-222. [CrossRef]

70. Boyce, S.; Lwaleed, B.; Kazmi, R. Homeostasis of Hemostasis: The Role of Endothelium. Semin. Thromb. Hemost. 2015, 41, 549-555. [CrossRef]

71. Loscalzo, J. Oxidative stress in endothelial cell dysfunction and thrombosis. Pathophysiol. Haemost. Thromb. 2002, 32, 359-360. [CrossRef] [PubMed]

72. Santulli, G. Endothelial cells: The heart attack of the Clones. Sci. Transl. Med. 2018, 10, eaar7529. [CrossRef] [PubMed]

73. Avogaro, A.; Albiero, M.; Menegazzo, L.; De Kreutzenberg, S.; Fadini, G.P. Endothelial dysfunction in diabetes: The role of reparatory mechanisms. Diabetes Care 2011, 34 (Suppl. 2), S285-S290. [CrossRef] [PubMed]

74. Goligorsky, M.S. Vascular endothelium in diabetes. Am. J. Physiol. Physiol. 2017, 312, F266-F275. [CrossRef] [PubMed]

75. Kaur, R.; Kaur, M.; Singh, J. Endothelial dysfunction and platelet hyperactivity in type 2 diabetes mellitus: Molecular insights and therapeutic strategies. Cardiovasc. Diabetol. 2018, 17, 121. [CrossRef]

76. Maamoun, H.; Abdelsalam, S.S.; Zeidan, A.; Korashy, H.M.; Agouni, A. Endoplasmic Reticulum Stress: A Critical Molecular Driver of Endothelial Dysfunction and Cardiovascular Disturbances Associated with Diabetes. Int. J. Mol. Sci. 2019, 20, 1658. [CrossRef]

77. Eringa, E.C.; Serné, E.H.; Meijer, R.I.; Schalkwijk, C.G.; Houben, A.J.H.M.; Stehouwer, C.D.A.; Smulders, Y.M.; Van Hinsbergh, V.W.M. Endothelial dysfunction in (pre)diabetes: Characteristics, causative mechanisms and pathogenic role in type 2 diabetes. Rev. Endocr. Metab. Disord. 2013, 14, 39-48. [CrossRef] 
78. Jansson, P.A. Endothelial dysfunction in insulin resistance and type 2 diabetes. J. Intern. Med. 2007, 262, 173-183. [CrossRef]

79. Gambardella, J.; Sardu, C.; Santulli, G. COVID-19 and endothelial dysfunction. JAMA 2020, in press.

80. Esler, M.; Esler, D. Can angiotensin receptor-blocking drugs perhaps be harmful in the COVID-19 pandemic? J. Hypertens. 2020, 38, 781-782. [CrossRef]

81. Fang, L.; Karakiulakis, G.; Roth, M. Are patients with hypertension and diabetes mellitus at increased risk for COVID-19 infection? Lancet Respir. Med. 2020, 8, e21. [CrossRef]

82. Nascimento, I.J.B.D.; Cacic, N.; Abdulazeem, H.M.; Von Groote, T.; Jayarajah, U.; Weerasekara, I.; Esfahani, M.A.; Civile, V.T.; Marusic, A.; Jeroncic, A.; et al. Novel Coronavirus Infection (COVID-19) in Humans: A Scoping Review and Meta-Analysis. Clin. Med. 2020, 9, 941. [CrossRef] [PubMed]

83. Wu, J.T.; Leung, K.; Bushman, M.; Kishore, N.; Niehus, R.; De Salazar, P.M.; Cowling, B.J.; Lipsitch, M.; Leung, G.M. Estimating clinical severity of COVID-19 from the transmission dynamics in Wuhan, China. Nat. Med. 2020, 26, 506-510. [CrossRef] [PubMed]

84. Guan, W.-J.; Ni, Z.-Y.; Hu, Y.; Liang, W.-H.; Ou, C.-Q.; He, J.-X.; Liu, L.; Shan, H.; Lei, C.-L.; Hui, D.S.; et al. Clinical Characteristics of Coronavirus Disease 2019 in China. N. Engl. J. Med. 2020, 382, 1708-1720. [CrossRef] [PubMed]

85. Huang, C.; Wang, Y.; Li, X.; Ren, L.; Zhao, J.; Hu, Y.; Zhang, L.; Fan, G.; Xu, J.; Gu, X.; et al. Clinical features of patients infected with 2019 novel coronavirus in Wuhan, China. Lancet 2020, 395, 497-506. [CrossRef]

86. Wang, D.; Hu, B.; Hu, C.; Zhu, F.; Liu, X.; Zhang, J.; Wang, B.; Xiang, H.; Cheng, Z.; Xiong, Y.; et al. Clinical Characteristics of 138 Hospitalized Patients With 2019 Novel Coronavirus-Infected Pneumonia in Wuhan, China. JAMA 2020, 323, 1061. [CrossRef]

87. Zhang, J.-J.; Dong, X.; Cao, Y.-Y.; Yuan, Y.-D.; Yang, Y.-B.; Yan, Y.-Q.; Akdis, C.A.; Gao, Y.-D. Clinical characteristics of 140 patients infected with SARS-CoV-2 in Wuhan, China. Allergy 2020. [CrossRef]

88. Williams, B.; Mancia, G.; Spiering, W.; Rosei, E.A.; Azizi, M.; Burnier, M.; Clement, D.L.; Coca, A.; De Simone, G.; Dominiczak, A.F.; et al. 2018 ESC/ESH Guidelines for the management of arterial hypertension. Eur. Heart J. 2018, 39, 3021-3104. [CrossRef]

89. Vaduganathan, M.; Vardeny, O.; Michel, T.; McMurray, J.J.V.; Pfeffer, M.A.; Solomon, S. ReninAngiotensin-Aldosterone System Inhibitors in Patients with Covid-19. N. Engl. J. Med. 2020, 382, 1653-1659. [CrossRef]

90. Gurwitz, D. Angiotensin receptor blockers as tentative SARS-CoV-2 therapeutics. Drug Dev. Res. 2020. [CrossRef]

91. Li, J.; Wang, X.; Chen, J.; Zhang, H.; Deng, A. Association of Renin-Angiotensin System Inhibitors With Severity or Risk of Death in Patients With Hypertension Hospitalized for Coronavirus Disease 2019 (COVID-19) Infection in Wuhan, China. JAMA Cardiol. 2020. [CrossRef] [PubMed]

92. Ferrario, C.M.; Jessup, J.; Chappell, M.; Averill, D.B.; Brosnihan, K.B.; Tallant, E.A.; Diz, D.I.; Gallagher, P.E. Effect of angiotensin-converting enzyme inhibition and angiotensin II receptor blockers on cardiac angiotensin-converting enzyme 2. Circulation 2005, 111, 2605-2610. [CrossRef] [PubMed]

93. Jessup, J.A.; Gallagher, P.E.; Averill, D.B.; Brosnihan, K.B.; Tallant, E.A.; Chappell, M.C.; Ferrario, C.M. Effect of angiotensin II blockade on a new congenic model of hypertension derived from transgenic Ren-2 rats. Am. J. Physiol. Circ. Physiol. 2006, 291, H2166-H2172. [CrossRef] [PubMed]

94. Igase, M.; Strawn, W.B.; Gallagher, P.E.; Geary, R.L.; Ferrario, C.M. Angiotensin II AT1 receptors regulate ACE2 and angiotensin-(1-7) expression in the aorta of spontaneously hypertensive rats. Am. J. Physiol. Circ. Physiol. 2005, 289, H1013-H1019. [CrossRef]

95. South, A.M.; Tomlinson, L.; Edmonston, D.; Hiremath, S.; Sparks, M.A. Controversies of renin-angiotensin system inhibition during the COVID-19 pandemic. Nat. Rev. Nephrol. 2020. [CrossRef]

96. Ferrario, C.M.; Ahmad, S.; Groban, L. Mechanisms by which angiotensin-receptor blockers increase ACE2 levels. Nat. Rev. Cardiol. 2020. [CrossRef]

97. Ishiyama, Y.; Gallagher, P.E.; Averill, D.B.; Tallant, E.A.; Brosnihan, K.B.; Ferrario, C.M. Upregulation of angiotensin-converting enzyme 2 after myocardial infarction by blockade of angiotensin II receptors. Hypertension 2004, 43, 970-976. [CrossRef]

98. Jin, H.-Y.; Song, B.; Oudit, G.Y.; Davidge, S.T.; Yu, H.-M.; Jiang, Y.-Y.; Gao, P.-J.; Zhu, D.-L.; Ning, G.; Kassiri, Z.; et al. ACE2 deficiency enhances angiotensin II-mediated aortic profilin-1 expression, inflammation and peroxynitrite production. PLOS ONE 2012, 7, e38502. [CrossRef] 
99. Soler, M.J.; Ye, M.; Wysocki, J.; William, J.; Lloveras, J.; Batlle, D. Localization of ACE2 in the renal vasculature: Amplification by angiotensin II type 1 receptor blockade using telmisartan. Am. J. Physiol. Physiol. 2009, 296, F398-F405. [CrossRef]

100. Patel, V.B.; Clarke, N.; Wang, Z.; Fan, D.; Parajuli, N.; Basu, R.; Putko, B.; Kassiri, Z.; Turner, A.J.; Oudit, G.Y. Angiotensin II induced proteolytic cleavage of myocardial ACE2 is mediated by TACE/ADAM-17: A positive feedback mechanism in the RAS. J. Mol. Cell. Cardiol. 2014, 66, 167-176. [CrossRef]

101. Yamamuro, M.; Yoshimura, M.; Nakayama, M.; Abe, K.; Sumida, H.; Sugiyama, S.; Saito, Y.; Nakao, K.; Yasue, H.; Ogawa, H. Aldosterone, but not angiotensin II, reduces angiotensin converting enzyme 2 gene expression levels in cultured neonatal rat cardiomyocytes. Circ. J. 2008, 72, 1346-1350. [CrossRef] [PubMed]

102. Keidar, S.; Gamliel-Lazarovich, A.; Kaplan, M.; Pavlotzky, E.; Hamoud, S.; Hayek, T.; Karry, R.; Abassi, Z. Mineralocorticoid Receptor Blocker Increases Angiotensin-Converting Enzyme 2 Activity in Congestive Heart Failure Patients. Circ. Res. 2005, 97, 946-953. [CrossRef] [PubMed]

103. Furuhashi, M.; Moniwa, N.; Mita, T.; Fuseya, T.; Ishimura, S.; Ohno, K.; Shibata, S.; Tanaka, M.; Watanabe, Y.; Akasaka, H.; et al. Urinary angiotensin-converting enzyme 2 in hypertensive patients may be increased by olmesartan, an angiotensin II receptor blocker. Am. J. Hypertens. 2015, 28, 15-21. [CrossRef] [PubMed]

104. Rice, G.I.; Thomas, D.A.; Grant, P.J.; Turner, A.J.; Hooper, N.M. Evaluation of angiotensin-converting enzyme (ACE), its homologue ACE2 and neprilysin in angiotensin peptide metabolism. Biochem. J. 2004, 383, 45-51. [CrossRef] [PubMed]

105. Nicholls, J.; Peiris, M. Good ACE, bad ACE do battle in lung injury, SARS. Nat. Med. 2005, 11, 821-822. [CrossRef] [PubMed]

106. Santos, R.A. Angiotensin-(1-7). Hypertension 2014, 63, 1138-1147. [CrossRef] [PubMed]

107. El-Hashim, A.Z.; Renno, W.M.; Raghupathy, R.; Abduo, H.T.; Akhtar, S.; Benter, I.F. Angiotensin-(1-7) inhibits allergic inflammation, via the MAS1 receptor, through suppression of ERK1/2- and NF-kappaB-dependent pathways. Br. J. Pharmacol. 2012, 166, 1964-1976. [CrossRef]

108. Kuba, K.; Imai, Y.; Rao, S.; Gao, H.; Guo, F.; Guan, B.; Huan, Y.; Yang, P.; Zhang, Y.; Deng, W.; et al. A crucial role of angiotensin converting enzyme 2 (ACE2) in SARS coronavirus-induced lung injury. Nat. Med. 2005, 11, 875-879. [CrossRef]

109. Povlsen, A.L.; Grimm, D.; Wehland, M.; Infanger, M.; Kruger, M. The Vasoactive Mas Receptor in Essential Hypertension. J. Clin. Med. 2020, 9, 267. [CrossRef]

110. Patel, A.B.; Verma, A. COVID-19 and Angiotensin-Converting Enzyme Inhibitors and Angiotensin Receptor Blockers: What Is the Evidence? JAMA 2020. [CrossRef]

111. de Simone, G.; Mancusi, C. Speculation is not evidence: Antihypertensive therapy and COVID-19. Eur. Heart J. Cardiovasc. Pharm. 2020. [CrossRef] [PubMed]

112. Iaccarino, G.; Borghi, C.; Cicero, A.F.G.; Ferri, C.; Minuz, P.; Muiesan, M.L.; Mulatero, P.; Mule, G.; Pucci, G.; Salvetti, M.; et al. Renin-Angiotensin System Inhibition in Cardiovascular Patients at the Time of COVID19: Much Ado for Nothing? A Statement of Activity from the Directors of the Board and the Scientific Directors of the Italian Society of Hypertension. High Blood Press. Cardiovasc. Prev. 2020, 27, 105-108. [CrossRef] [PubMed]

113. Sultana, J.; Trotta, F.; Addis, A.; Brown, J.S.; Gil, M.; Menniti-Ippolito, F.; Milozzi, F.; Suissa, S.; Trifiro, G. Healthcare Database Networks for Drug Regulatory Policies: International Workshop on the Canadian, US and Spanish Experience and Future Steps for Italy. Drug Saf. 2020, 43, 1-5. [CrossRef] [PubMed]

114. Talreja, H.; Tan, J.; Dawes, M.; Supershad, S.; Rabindranath, K.; Fisher, J.; Valappil, S.; van der Merwe, V.; Wong, L.; van der Merwe, W.; et al. A consensus statement on the use of angiotensin receptor blockers and angiotensin converting enzyme inhibitors in relation to COVID-19 (corona virus disease 2019). N. Z. Med. J. 2020, 133, 85-87.

115. Zhang, P.; Zhu, L.; Cai, J.; Lei, F.; Qin, J.J.; Xie, J.; Liu, Y.M.; Zhao, Y.C.; Huang, X.; Lin, L.; et al. Association of Inpatient Use of Angiotensin Converting Enzyme Inhibitors and Angiotensin II Receptor Blockers with Mortality Among Patients With Hypertension Hospitalized With COVID-19. Circ. Res. 2020. [CrossRef]

116. Yang, G.; Tan, Z.; Zhou, L.; Yang, M.; Peng, L.; Liu, J.; Cai, J.; Yang, R.; Han, J.; Huang, Y.; et al. Effects Of ARBs And ACEIs On Virus Infection, Inflammatory Status And Clinical Outcomes In COVID-19 Patients With Hypertension: A Single Center Retrospective Study. Hypertension 2020. [CrossRef]

117. Mehra, M.; Desai, S.; Kuy, S.; Henry, T.; Patel, A. Cardiovascular Disease, Drug Therapy, and Mortality in Covid-19. NEJM 2019, in press. [CrossRef] 
118. Reynolds, H.; Adhikari, S.; Pulgarin, C.; Troxel, A.; Iturrate, E.; Johnson, S.; Hausvater, A.; Newman, J.; Berger, J.; Bangalore, S.; et al. Renin-Angiotensin-Aldosterone System Inhibitors and Risk of Covid-19. NEJM 2019, in press. [CrossRef]

119. Mancia, G.; Rea, F.; Ludergnani, M.; Apolone, G.; Corrao, G. Renin-Angiotensin-Aldosterone System Inhibitors and Risk of Covid-19. NEJM 2019, in press.

120. Rajagopalan, S.; Harrison, D.G. Reversing endothelial dysfunction with ACE inhibitors. A new trend. Circulation 1996, 94, 240-243. [CrossRef]

121. Beckman, J.A.; Creager, M.A. The nonlipid effects of statins on endothelial function. Trends Cardiovasc. Med. 2006, 16, 156-162. [CrossRef]

122. Ruszkowski, P.; Masajtis-Zagajewska, A.; Nowicki, M. Effects of combined statin and ACE inhibitor therapy on endothelial function and blood pressure in essential hypertension-A randomised double-blind, placebo controlled crossover study. J. Renin Angiotensin Aldosterone Syst. 2019, 20, 1470320319868890. [CrossRef]

123. Blum, A.; Shamburek, R. The pleiotropic effects of statins on endothelial function, vascular inflammation, immunomodulation and thrombogenesis. Atherosclerosis 2009, 203, 325-330. [CrossRef]

124. Glowacka, I.; Bertram, S.; Herzog, P.; Pfefferle, S.; Steffen, I.; Muench, M.O.; Simmons, G.; Hofmann, H.; Kuri, T.; Weber, F.; et al. Differential downregulation of ACE2 by the spike proteins of severe acute respiratory syndrome coronavirus and human coronavirus NL63. J. Virol. 2010, 84, 1198-1205. [CrossRef]

125. Luque, M.; Martin, P.; Martell, N.; Fernandez, C.; Brosnihan, K.B.; Ferrario, C.M. Effects of captopril related to increased levels of prostacyclin and angiotensin-(1-7) in essential hypertension. J. Hypertens. 1996, 14, 799-805. [CrossRef]

126. Chen, L.; Hao, G. The role of angiotensin-converting enzyme 2 in coronaviruses/influenza viruses and cardiovascular disease. Cardiovasc. Res. 2020. [CrossRef]

127. Murray, E.; Tomaszewski, M.; Guzik, T.J. Binding of SARS-CoV-2 and angiotensin-converting enzyme 2: Clinical implications. Cardiovasc. Res. 2020. [CrossRef]

128. Sunden-Cullberg, J. Chronic Use of Angiotensin-Converting Enzyme Inhibitors and Angiotensin II Receptor Blockers Is High Among Intensive Care Unit Patients With Non-COVID-19 Sepsis but Carry a Moderately Increased Risk of Death. Hypertension 2020. [CrossRef]

129. Fan, Z.; Wu, G.; Yue, M.; Ye, J.; Chen, Y.; Xu, B.; Shu, Z.; Zhu, J.; Lu, N.; Tan, X. Hypertension and hypertensive left ventricular hypertrophy are associated with ACE2 genetic polymorphism. Life Sci. 2019, 225, 39-45. [CrossRef]

130. Pinheiro, D.S.; Santos, R.S.; Jardim, P.; Silva, E.G.; Reis, A.A.S.; Pedrino, G.R.; Ulhoa, C.J. The combination of ACE I/D and ACE2 G8790A polymorphisms revels susceptibility to hypertension: A genetic association study in Brazilian patients. PLoS ONE 2019, 14, e0221248. [CrossRef]

131. Lackland, D.T. Racial differences in hypertension: Implications for high blood pressure management. Am. J. Med. Sci. 2014, 348, 135-138. [CrossRef] [PubMed]

132. Bonow, R.O.; Fonarow, G.C.; O'Gara, P.T.; Yancy, C.W. Association of Coronavirus Disease 2019 (COVID-19) With Myocardial Injury and Mortality. JAMA Cardiol. 2020. [CrossRef] [PubMed]

133. Guo, T.; Fan, Y.; Chen, M.; Wu, X.; Zhang, L.; He, T.; Wang, H.; Wan, J.; Wang, X.; Lu, Z. Cardiovascular Implications of Fatal Outcomes of Patients With Coronavirus Disease 2019 (COVID-19). JAMA Cardiol. 2020. [CrossRef]

134. De Filippo, O.; D’Ascenzo, F.; Angelini, F.; Bocchino, P.P.; Conrotto, F.; Saglietto, A.; Secco, G.G.; Campo, G.; Gallone, G.; Verardi, R.; et al. Reduced Rate of Hospital Admissions for ACS during Covid-19 Outbreak in Northern Italy. New Engl. J. Med. 2020. [CrossRef]

135. Garcia, S.; Albaghdadi, M.S.; Meraj, P.M.; Schmidt, C.; Garberich, R.; Jaffer, F.A.; Dixon, S.; Rade, J.J.; Tannenbaum, M.; Chambers, J.; et al. Reduction in ST-Segment Elevation Cardiac Catheterization Laboratory Activations in the United States during COVID-19 Pandemic. J. Am. Coll Cardiol. 2020. [CrossRef]

136. Yang, X.; Yu, Y.; Xu, J.; Shu, H.; Xia, J.; Liu, H.; Wu, Y.; Zhang, L.; Yu, Z.; Fang, M.; et al. Clinical course and outcomes of critically ill patients with SARS-CoV-2 pneumonia in Wuhan, China: A single-centered, retrospective, observational study. Lancet Respir. Med. 2020, 8, 475-481. [CrossRef]

137. Fanelli, V.; Fiorentino, M.; Cantaluppi, V.; Gesualdo, L.; Stallone, G.; Ronco, C.; Castellano, G. Acute kidney injury in SARS-CoV-2 infected patients. Crit. Care 2020, 24, 155. [CrossRef]

138. Cheng, Y.; Luo, R.; Wang, K.; Zhang, M.; Wang, Z.; Dong, L.; Li, J.; Yao, Y.; Ge, S.; Xu, G. Kidney disease is associated with in-hospital death of patients with COVID-19. Kidney Int. 2020. [CrossRef] 
139. Henry, B.M.; Lippi, G. Chronic kidney disease is associated with severe coronavirus disease 2019 (COVID-19) infection. Int. Urol. Nephrol. 2020. [CrossRef]

140. Ye, M.; Wysocki, J.; William, J.; Soler, M.J.; Cokic, I.; Batlle, D. Glomerular localization and expression of Angiotensin-converting enzyme 2 and Angiotensin-converting enzyme: Implications for albuminuria in diabetes. J. Am. Soc. Nephrol. 2006, 17, 3067-3075. [CrossRef] [PubMed]

141. Han, L.; We, X.; Liu, C.; Volpe, G.; Wang, Z. Single-cell atlas of a non-human primate reveals new pathogenic mechanisms of COVID-19. bioRXiv 2020. [CrossRef]

142. Varga, Z.; Flammer, A.J.; Steiger, P.; Haberecker, M.; Andermatt, R.; Zinkernagel, A.S.; Mehra, M.R.; Schuepbach, R.A.; Ruschitzka, F.; Moch, H. Endothelial cell infection and endotheliitis in COVID-19. Lancet 2020, 395, 1417-1418. [CrossRef]

143. Su, H.; Yang, M.; Wan, C.; Yi, L.X.; Tang, F.; Zhu, H.Y.; Yi, F.; Yang, H.C.; Fogo, A.B.; Nie, X.; et al. Renal histopathological analysis of 26 postmortem findings of patients with COVID-19 in China. Kidney Int. 2020. [CrossRef] [PubMed]

144. Gentile, S.; Strollo, F.; Ceriello, A. COVID-19 Infection in italian people with diabetes: Lessons learned for our future (an experience to be used). Diabetes Res. Clin. Pract. 2020, 108137. [CrossRef] [PubMed]

145. Ma, R.C.W.; Holt, R.I.G. COVID-19 and diabetes. Diabet. Med. 2020, 37, 723-725. [CrossRef] [PubMed]

146. Muniyappa, R.; Gubbi, S. COVID-19 Pandemic, Corona Viruses, and Diabetes Mellitus. Am. J. Physiol. Endocrinol. Metab. 2020. [CrossRef]

147. Arentz, M.; Yim, E.; Klaff, L.; Lokhandwala, S.; Riedo, F.X.; Chong, M.; Lee, M. Characteristics and Outcomes of 21 Critically Ill Patients With COVID-19 in Washington State. JAMA 2020, 323, 1612. [CrossRef]

148. Bornstein, S.R.; Dalan, R.; Hopkins, D.; Mingrone, G.; Boehm, B.O. Endocrine and metabolic link to coronavirus infection. Nat. Rev. Endocrinol. 2020. [CrossRef]

149. Remuzzi, A.; Remuzzi, G. COVID-19 and Italy: What next? Lancet 2020, 395, 1225-1228. [CrossRef]

150. Fadini, G.P.; Morieri, M.L.; Longato, E.; Avogaro, A. Prevalence and impact of diabetes among people infected with SARS-CoV-2. J. Endocrinol. Investig. 2020. [CrossRef]

151. Li, B.; Yang, J.; Zhao, F.; Zhi, L.; Wang, X.; Liu, L.; Bi, Z.; Zhao, Y. Prevalence and impact of cardiovascular metabolic diseases on COVID-19 in China. Clin. Res. Cardiol. 2020, 109, 531-538. [CrossRef] [PubMed]

152. Yang, J.K.; Feng, Y.; Yuan, M.Y.; Yuan, S.Y.; Fu, H.J.; Wu, B.Y.; Sun, G.Z.; Yang, G.R.; Zhang, X.L.; Wang, L.; et al. Plasma glucose levels and diabetes are independent predictors for mortality and morbidity in patients with SARS. Diabet. Med. 2006, 23, 623-628. [CrossRef] [PubMed]

153. Simonnet, A.; Chetboun, M.; Poissy, J.; Raverdy, V.; Noulette, J.; Duhamel, A.; Labreuche, J.; Mathieu, D.; Pattou, F.; Jourdain, M. High prevalence of obesity in severe acute respiratory syndrome coronavirus-2 (SARS-CoV-2) requiring invasive mechanical ventilation. Obesity (Silver Spring) 2020. [CrossRef] [PubMed]

154. Wang, A.; Zhao, W.; Xu, Z.; Gu, J. Timely blood glucose management for the outbreak of 2019 novel coronavirus disease (COVID-19) is urgently needed. Diabetes Res. Clin. Pract. 2020, 162, 108118. [CrossRef] [PubMed]

155. Yang, J.K.; Lin, S.S.; Ji, X.J.; Guo, L.M. Binding of SARS coronavirus to its receptor damages islets and causes acute diabetes. Acta Diabetol. 2010, 47, 193-199. [CrossRef] [PubMed]

156. Lu, C.L.; Wang, Y.; Yuan, L.; Li, Y.; Li, X.Y. The angiotensin-converting enzyme 2/angiotensin (1-7)/Mas axis protects the function of pancreatic beta cells by improving the function of islet microvascular endothelial cells. Int. J. Mol. Med. 2014, 34, 1293-1300. [CrossRef]

157. Xuan, X.; Gao, F.; Ma, X.; Huang, C.; Wang, Y.; Deng, H.; Wang, S.; Li, W.; Yuan, L. Activation of ACE2/angiotensin (1-7) attenuates pancreatic beta cell dedifferentiation in a high-fat-diet mouse model. Metabolism 2018, 81, 83-96. [CrossRef]

158. Shoemaker, R.; Yiannikouris, F.; Thatcher, S.; Cassis, L. ACE2 deficiency reduces beta-cell mass and impairs beta-cell proliferation in obese C57BL/6 mice. Am. J. Physiol. Endocrinol. Metab. 2015, 309, E621-E631. [CrossRef]

159. Bindom, S.M.; Lazartigues, E. The sweeter side of ACE2: Physiological evidence for a role in diabetes. Mol. Cell Endocrinol. 2009, 302, 193-202. [CrossRef]

160. Roca-Ho, H.; Riera, M.; Palau, V.; Pascual, J.; Soler, M.J. Characterization of ACE and ACE2 Expression within Different Organs of the NOD Mouse. Int. J. Mol. Sci. 2017, 18, 563. [CrossRef] 
161. Blodgett, D.M.; Nowosielska, A.; Afik, S.; Pechhold, S.; Cura, A.J.; Kennedy, N.J.; Kim, S.; Kucukural, A.; Davis, R.J.; Kent, S.C.; et al. Novel Observations From Next-Generation RNA Sequencing of Highly Purified Human Adult and Fetal Islet Cell Subsets. Diabetes 2015, 64, 3172-3181. [CrossRef] [PubMed]

162. Wang, H.; Bender, A.; Wang, P.; Karakose, E.; Inabnet, W.B.; Libutti, S.K.; Arnold, A.; Lambertini, L.; Stang, M.; Chen, H.; et al. Insights into beta cell regeneration for diabetes via integration of molecular landscapes in human insulinomas. Nat. Commun. 2017, 8, 767. [CrossRef] [PubMed]

163. Li, J.; Wang, X.; Chen, J.; Zuo, X.; Zhang, H.; Deng, A. COVID-19 infection may cause ketosis and ketoacidosis. Diabetes Obes. Metab. 2020. [CrossRef] [PubMed]

164. Stoian, A.P.; Banerjee, Y.; Rizvi, A.A.; Rizzo, M. Diabetes and the COVID-19 Pandemic: How Insights from Recent Experience Might Guide Future Management. Metab. Syndr. Relat. Disord. 2020. [CrossRef] [PubMed]

165. Zhang, M.D.; Xiao, M.; Zhang, S.; Xia, P.; Caio, W.; Jiang, W. Coagulopathy and Antiphospholipid Antibodies in Patients with Covid-19. NEJM 2020, 382, e38. [CrossRef] [PubMed]

166. Zhou, B.; She, J.; Wang, Y.; Ma, X. Venous thrombosis and arteriosclerosis obliterans of lower extremities in a very severe patient with 2019 novel coronavirus disease: A case report. J. Thromb. Thrombolysis 2020. [CrossRef]

167. Tang, N.; Li, D.; Wang, X.; Sun, Z. Abnormal coagulation parameters are associated with poor prognosis in patients with novel coronavirus pneumonia. J. Thromb. Haemost. 2020, 18, 844-847. [CrossRef]

168. Lin, L.; Lu, L.; Cao, W.; Li, T. Hypothesis for potential pathogenesis of SARS-CoV-2 infection-a review of immune changes in patients with viral pneumonia. Emerg. Microbes Infect. 2020, 9, 727-732. [CrossRef]

169. Iba, T.; Levy, J.H.; Warkentin, T.E.; Thachil, J.; van der Poll, T.; Levi, M. Scientific, Standardization Committee on DIC, the S, Standardization Committee on P, Critical Care of the International Society on T and Haemostasis. Diagnosis and management of sepsis-induced coagulopathy and disseminated intravascular coagulation. J. Thromb. Haemost. 2019, 17, 1989-1994. [CrossRef]

170. Escher, R.; Breakey, N.; Lammle, B. Severe COVID-19 infection associated with endothelial activation. Thromb. Res. 2020, 190, 62. [CrossRef]

171. McCormack, J.J.; Lopes da Silva, M.; Ferraro, F.; Patella, F.; Cutler, D.F. Weibel-Palade bodies at a glance. J. Cell Sci. 2017, 130, 3611-3617. [CrossRef] [PubMed]

172. Liu, Y.; Yang, Y.; Zhang, C.; Huang, F.; Wang, F.; Yuan, J.; Wang, Z.; Li, J.; Li, J.; Feng, C.; et al. Clinical and biochemical indexes from 2019-nCoV infected patients linked to viral loads and lung injury. Sci. China Life Sci. 2020, 63, 364-374. [CrossRef] [PubMed]

173. Williams, B.; Baker, A.Q.; Gallacher, B.; Lodwick, D. Angiotensin II increases vascular permeability factor gene expression by human vascular smooth muscle cells. Hypertension 1995, 25, 913-917. [CrossRef] [PubMed]

174. Victorino, G.P.; Newton, C.R.; Curran, B. Effect of angiotensin II on microvascular permeability. J. Surg. Res. 2002, 104, 77-81. [CrossRef] [PubMed]

175. Dielis, A.W.; Smid, M.; Spronk, H.M.; Hamulyak, K.; Kroon, A.A.; ten Cate, H.; de Leeuw, P.W. The prothrombotic paradox of hypertension: Role of the renin-angiotensin and kallikrein-kinin systems. Hypertension 2005, 46, 1236-1242. [CrossRef]

176. Watanabe, T.; Barker, T.A.; Berk, B.C. Angiotensin II and the endothelium: Diverse signals and effects. Hypertension 2005, 45, 163-169. [CrossRef]

177. Celi, A.; Cianchetti, S.; Dell'Omo, G.; Pedrinelli, R. Angiotensin II, tissue factor and the thrombotic paradox of hypertension. Expert Rev. Cardiovasc. Ther. 2010, 8, 1723-1729. [CrossRef]

178. Jagroop, I.A.; Mikhailidis, D.P. Angiotensin II can induce and potentiate shape change in human platelets: Effect of losartan. J. Hum. Hypertens. 2000, 14, 581-585. [CrossRef]

179. Ding, Y.A.; MacIntyre, D.E.; Kenyon, C.J.; Semple, P.F. Angiotensin II effects on platelet function. J. Hypertens. Suppl. 1985, 3, S251-S253. [CrossRef]

180. Larsson, P.T.; Schwieler, J.H.; Wallen, N.H. Platelet activation during angiotensin II infusion in healthy volunteers. Blood Coagul. Fibrinolysis 2000, 11, 61-69. [CrossRef]

181. Langeggen, H.; Berge, K.E.; Macor, P.; Fischetti, F.; Tedesco, F.; Hetland, G.; Berg, K.; Johnson, E. Detection of mRNA for the terminal complement components C5, C6, C8 and C9 in human umbilical vein endothelial cells in vitro. Apmis 2001, 109, 73-78. [CrossRef] [PubMed]

182. Langeggen, H.; Pausa, M.; Johnson, E.; Casarsa, C.; Tedesco, F. The endothelium is an extrahepatic site of synthesis of the seventh component of the complement system. Clin. Exp. Immunol. 2000, 121, 69-76. [CrossRef] [PubMed] 
183. Dauchel, H.; Julen, N.; Lemercier, C.; Daveau, M.; Ozanne, D.; Fontaine, M.; Ripoche, J. Expression of complement alternative pathway proteins by endothelial cells. Differential regulation by interleukin 1 and glucocorticoids. Eur. J. Immunol. 1990, 20, 1669-1675. [CrossRef] [PubMed]

184. Warren, H.B.; Pantazis, P.; Davies, P.F. The third component of complement is transcribed and secreted by cultured human endothelial cells. Am. J. Pathol. 1987, 129, 9-13. [PubMed]

185. Johnson, E.; Hetland, G. Human umbilical vein endothelial cells synthesize functional C3, C5, C6, C8 and C9 in vitro. Scand J. Immunol. 1991, 33, 667-671. [CrossRef] [PubMed]

186. Shagdarsuren, E.; Wellner, M.; Braesen, J.H.; Park, J.K.; Fiebeler, A.; Henke, N.; Dechend, R.; Gratze, P.; Luft, F.C.; Muller, D.N. Complement activation in angiotensin II-induced organ damage. Circ. Res. 2005, 97, 716-724. [CrossRef]

187. Ruan, C.C.; Gao, P.J. Role of Complement-Related Inflammation and Vascular Dysfunction in Hypertension. Hypertension 2019, 73, 965-971. [CrossRef]

188. Fischetti, F.; Tedesco, F. Cross-talk between the complement system and endothelial cells in physiologic conditions and in vascular diseases. Autoimmunity 2006, 39, 417-428. [CrossRef]

189. Risitano, A.M.; Mastellos, D.C.; Huber-Lang, M.; Yancopoulou, D.; Garlanda, C.; Ciceri, F.; Lambris, J.D. Complement as a target in COVID-19? Nat. Rev. Immunol. 2020. [CrossRef]

190. Schulz, C.; Engelmann, B.; Massberg, S. Crossroads of coagulation and innate immunity: The case of deep vein thrombosis. J. Thromb. Haemost. 2013, 11 (Suppl. 1), 233-241. [CrossRef]

191. abret, N.; Britton, G.J.; Gruber, C.; Hegde, S.; Kim, J.; Kuksin, M.; Levantovsky, R.; Malle, L.; Moreira, A.; Park, M.D.; et al. The Sinai Immunology Review Project. Immunology of COVID-19: Current state of the science. Immunity 2020. [CrossRef]

192. Steinberg, B.E.; Goldenberg, N.M.; Lee, W.L. Do viral infections mimic bacterial sepsis? The role of microvascular permeability: A review of mechanisms and methods. Antiviral. Res. 2012, 93, 2-15. [CrossRef] [PubMed]

193. Zeng, H.; Pappas, C.; Belser, J.A.; Houser, K.V.; Zhong, W.; Wadford, D.A.; Stevens, T.; Balczon, R.; Katz, J.M.; Tumpey, T.M. Human pulmonary microvascular endothelial cells support productive replication of highly pathogenic avian influenza viruses: Possible involvement in the pathogenesis of human H5N1 virus infection. J. Virol. 2012, 86, 667-678. [CrossRef] [PubMed]

194. Maniatis, N.A.; Orfanos, S.E. The endothelium in acute lung injury/acute respiratory distress syndrome. Curr. Opin. Crit. Care 2008, 14, 22-30. [CrossRef] [PubMed]

195. Polverino, F.; Celli, B.R.; Owen, C.A. COPD as an endothelial disorder: Endothelial injury linking lesions in the lungs and other organs? (2017 Grover Conference Series). Pulm. Circ. 2018, 8, 2045894018758528. [CrossRef] [PubMed]

196. Millar, F.R.; Summers, C.; Griffiths, M.J.; Toshner, M.R.; Proudfoot, A.G. The pulmonary endothelium in acute respiratory distress syndrome: Insights and therapeutic opportunities. Thorax 2016, 71, 462-473. [CrossRef]

197. Armstrong, S.M.; Wang, C.; Tigdi, J.; Si, X.; Dumpit, C.; Charles, S.; Gamage, A.; Moraes, T.J.; Lee, W.L. Influenza infects lung microvascular endothelium leading to microvascular leak: Role of apoptosis and claudin-5. PLoS ONE 2012, 7, e47323. [CrossRef]

198. Chan, M.C.; Chan, R.W.; Yu, W.C.; Ho, C.C.; Chui, W.H.; Lo, C.K.; Yuen, K.M.; Guan, Y.I.; Nicholls, J.M.; Peiris, J.S. Influenza H5N1 virus infection of polarized human alveolar epithelial cells and lung microvascular endothelial cells. Respir. Res. 2009, 10, 102. [CrossRef]

199. Lee, N.; Hui, D.; Wu, A.; Chan, P.; Cameron, P.; Joynt, G.M.; Ahuja, A.; Yung, M.Y.; Leung, C.B.; To, K.F.; et al. A major outbreak of severe acute respiratory syndrome in Hong Kong. N. Engl. J. Med. 2003, 348, 1986-1994. [CrossRef]

200. Wong, R.S.; Wu, A.; To, K.F.; Lee, N.; Lam, C.W.; Wong, C.K.; Chan, P.K.; Ng, M.H.; Yu, L.M.; Hui, D.S.; et al. Haematological manifestations in patients with severe acute respiratory syndrome: Retrospective analysis. BMJ 2003, 326, 1358-1362. [CrossRef]

201. Xiang-Hua, Y.; Le-Min, W.; Ai-Bin, L.; Zhu, G.; Riquan, L.; Xu-You, Z.; Wei-Wei, R.; Ye-Nan, W. Severe acute respiratory syndrome and venous thromboembolism in multiple organs. Am. J. Respir. Crit. Care Med. 2010, 182, 436-437. [CrossRef] [PubMed]

202. de Wit, E.; van Doremalen, N.; Falzarano, D.; Munster, V.J. SARS and MERS: Recent insights into emerging coronaviruses. Nat. Rev. Microbiol. 2016, 14, 523-534. [CrossRef] [PubMed] 
203. Bunce, P.E.; High, S.M.; Nadjafi, M.; Stanley, K.; Liles, W.C.; Christian, M.D. Pandemic H1N1 influenza infection and vascular thrombosis. Clin. Infect. Dis. 2011, 52, e14-e17. [CrossRef]

204. Huzmeli, C.; Saglam, M.; Arikan, A.; Doner, B.; Akinci, G.; Candan, F. Infrarenal Aorta Thrombosis Associated with H1N1 Influenza A Virus Infection. Case Rep. Infect. Dis. 2016, 2016, 9567495. [CrossRef] [PubMed]

205. Ishiguro, T.; Matsuo, K.; Fujii, S.; Takayanagi, N. Acute thrombotic vascular events complicating influenza-associated pneumonia. Respir. Med. Case Rep. 2019, 28, 100884. [CrossRef] [PubMed]

206. Iwasaki, A.; Medzhitov, R. A new shield for a cytokine storm. Cell 2011, 146, 861-862. [CrossRef]

207. Tscherne, D.M.; Garcia-Sastre, A. Virulence determinants of pandemic influenza viruses. J. Clin. Investig. 2011, 121, 6-13. [CrossRef]

208. Canna, S.W.; Behrens, E.M. Making sense of the cytokine storm: A conceptual framework for understanding, diagnosing, and treating hemophagocytic syndromes. Pediatr. Clin. N. Am. 2012, 59, 329-344. [CrossRef]

209. Chaudhry, H.; Zhou, J.; Zhong, Y.; Ali, M.M.; McGuire, F.; Nagarkatti, P.S.; Nagarkatti, M. Role of cytokines as a double-edged sword in sepsis. In Vivo 2013, 27, 669-684.

210. Bracaglia, C.; Prencipe, G.; De Benedetti, F. Macrophage Activation Syndrome: Different mechanisms leading to a one clinical syndrome. Pediatr. Rheumatol. Online J. 2017, 15, 5. [CrossRef]

211. Hayden, A.; Park, S.; Giustini, D.; Lee, A.Y.; Chen, L.Y. Hemophagocytic syndromes (HPSs) including hemophagocytic lymphohistiocytosis (HLH) in adults: A systematic scoping review. Blood Rev. 2016, 30, 411-420. [CrossRef] [PubMed]

212. Mehta, P.; McAuley, D.F.; Brown, M.; Sanchez, E.; Tattersall, R.S.; Manson, J.J.; Hlh Across Speciality Collaboration UK. COVID-19: Consider cytokine storm syndromes and immunosuppression. Lancet 2020, 395, 1033-1034. [CrossRef]

213. Gattinoni, L.; Coppola, S.; Cressoni, M.; Busana, M.; Rossi, S.; Chiumello, D. Covid-19 Does Not Lead to a “Typical” Acute Respiratory Distress Syndrome. Am. J. Respir. Crit. Care Med. 2020. [CrossRef] [PubMed]

214. Pedersen, S.F.; Ho, Y.C. SARS-CoV-2: A storm is raging. J. Clin. Investig. 2020, 130, 2202-2205. [CrossRef] [PubMed]

215. Staedtke, V.; Bai, R.Y.; Kim, K.; Darvas, M.; Davila, M.L.; Riggins, G.J.; Rothman, P.B.; Papadopoulos, N.; Kinzler, K.W.; Vogelstein, B.; et al. Disruption of a self-amplifying catecholamine loop reduces cytokine release syndrome. Nature 2018, 564, 273-277. [CrossRef]

216. Sinha, P.; Delucchi, K.L.; McAuley, D.F.; O'Kane, C.M.; Matthay, M.A.; Calfee, C.S. Development and validation of parsimonious algorithms to classify acute respiratory distress syndrome phenotypes: A secondary analysis of randomised controlled trials. Lancet Respir. Med. 2020, 8, 247-257. [CrossRef]

217. Qin, C.; Zhou, L.; Hu, Z.; Zhang, S.; Yang, S.; Tao, Y.; Xie, C.; Ma, K.; Shang, K.; Wang, W.; et al. Dysregulation of immune response in patients with COVID-19 in Wuhan, China. Clin. Infect. Dis. 2020. [CrossRef]

218. Teijaro, J.R.; Walsh, K.B.; Cahalan, S.; Fremgen, D.M.; Roberts, E.; Scott, F.; Martinborough, E.; Peach, R.; Oldstone, M.B.; Rosen, H. Endothelial cells are central orchestrators of cytokine amplification during influenza virus infection. Cell 2011, 146, 980-991. [CrossRef]

219. Sorriento, D.; Santulli, G.; Del Giudice, C.; Anastasio, A.; Trimarco, B.; Iaccarino, G. Endothelial cells are able to synthesize and release catecholamines both in vitro and in vivo. Hypertension 2012, 60, 129-136. [CrossRef]

220. Xie, Y.; Wang, X.; Yang, P.; Shutong, Z. COVID-19 complicated by acute pulmonary embolism. Radiology 2020, 2, e200067. [CrossRef]

221. Danzi, G.B.; Loffi, M.; Galeazzi, G.; Gherbesi, E. Acute pulmonary embolism and COVID-19 pneumonia: A random association? Eur. Heart J. 2020. [CrossRef]

222. Leonard-Lorant, I.; Delabranche, X.; Severac, F.; Helms, J.; Pauzet, C.; Collange, O.; Schneider, F.; Labani, A.; Bilbault, P.; Moliere, S.; et al. Acute Pulmonary Embolism in COVID-19 Patients on CT Angiography and Relationship to D-Dimer Levels. Radiology 2020, 201561. [CrossRef]

223. Jolobe, O.M.P. Similarities Between Community-Acquired Pneumonia and Pulmonary Embolism. Am. J. Med. 2019, 132, e863. [CrossRef]

224. Santulli, G. MicroRNAs and Endothelial (Dys) Function. J. Cell Physiol. 2016, 231, 1638-1644. [CrossRef] [PubMed]

225. Yuan, Q.; Yang, J.; Santulli, G.; Reiken, S.R.; Wronska, A.; Kim, M.M.; Osborne, B.W.; Lacampagne, A.; Yin, Y.; Marks, A.R. Maintenance of normal blood pressure is dependent on IP3R1-mediated regulation of eNOS. Proc. Natl. Acad. Sci. USA 2016, 113, 8532-8537. [CrossRef] [PubMed] 
226. Gando, S.; Levi, M.; Toh, C.H. Disseminated intravascular coagulation. Nat. Rev. Dis. Primers. 2016, 2, 16037. [CrossRef] [PubMed]

227. Walborn, A.; Rondina, M.; Mosier, M.; Fareed, J.; Hoppensteadt, D. Endothelial Dysfunction Is Associated with Mortality and Severity of Coagulopathy in Patients with Sepsis and Disseminated Intravascular Coagulation. Clin. Appl. Thromb. Hemost. 2019, 25, 1076029619852163. [CrossRef] [PubMed]

228. Tang, N.; Bai, H.; Chen, X.; Gong, J.; Li, D.; Sun, Z. Anticoagulant treatment is associated with decreased mortality in severe coronavirus disease 2019 patients with coagulopathy. J. Thromb. Haemost. 2020. [CrossRef] [PubMed]

229. Rubin, E.J.; Baden, L.R.; Morrissey, S. Audio Interview: New Research on Possible Treatments for Covid-19. New Engl. J. Med. 2020, 382, e30. [CrossRef]

230. Ahn, D.G.; Shin, H.J.; Kim, M.H.; Lee, S.; Kim, H.S.; Myoung, J.; Kim, B.T.; Kim, S.J. Current Status of Epidemiology, Diagnosis, Therapeutics, and Vaccines for Novel Coronavirus Disease 2019 (COVID-19). J. Microbiol. Biotechnol. 2020, 30, 313-324. [CrossRef]

231. Xu, X.; Han, M.; Li, T.; Sun, W.; Wang, D.; Fu, B.; Zhou, Y.; Zheng, X.; Yang, Y.; Li, X.; et al. Effective treatment of severe COVID-19 patients with tocilizumab. Proc. Natl. Acad. Sci. USA 2020, 202005615. [CrossRef] [PubMed]

232. Ruiz-Limon, P.; Ortega, R.; Arias de la Rosa, I.; Abalos-Aguilera, M.D.C.; Perez-Sanchez, C.; Jimenez-Gomez, Y.; Peralbo-Santaella, E.; Font, P.; Ruiz-Vilches, D.; Ferrin, G.; et al. Tocilizumab improves the proatherothrombotic profile of rheumatoid arthritis patients modulating endothelial dysfunction, NETosis, and inflammation. Transl. Res. 2017, 183, 87-103. [CrossRef] [PubMed]

233. Kajikawa, M.; Higashi, Y.; Tomiyama, H.; Maruhashi, T.; Kurisu, S.; Kihara, Y.; Mutoh, A.; Ueda, S.I. Effect of short-term colchicine treatment on endothelial function in patients with coronary artery disease. Int. J. Cardiol. 2019, 281, 35-39. [CrossRef] [PubMed]

234. Parchure, N.; Zouridakis, E.G.; Kaski, J.C. Effect of azithromycin treatment on endothelial function in patients with coronary artery disease and evidence of Chlamydia pneumoniae infection. Circulation 2002, 105, 1298-1303. [CrossRef] [PubMed]

235. Luo, T.; Chen, B.; Zhao, Z.; He, N.; Zeng, Z.; Wu, B.; Fukushima, Y.; Dai, M.; Huang, Q.; Xu, D.; et al. Histamine $\mathrm{H} 2$ receptor activation exacerbates myocardial ischemia/reperfusion injury by disturbing mitochondrial and endothelial function. Basic Res. Cardiol. 2013, 108, 342. [CrossRef] [PubMed]

236. Yazdany, J.; Kim, A.H.J. Use of Hydroxychloroquine and Chloroquine During the COVID-19 Pandemic: What Every Clinician Should Know. Ann. Intern. Med. 2020. [CrossRef]

237. Le, N.T.; Takei, Y.; Izawa-Ishizawa, Y.; Heo, K.S.; Lee, H.; Smrcka, A.V.; Miller, B.L.; Ko, K.A.; Ture, S.; Morrell, C.; et al. Identification of activators of ERK5 transcriptional activity by high-throughput screening and the role of endothelial ERK5 in vasoprotective effects induced by statins and antimalarial agents. J. Immunol. 2014, 193, 3803-3815. [CrossRef]

238. Rahman, R.; Murthi, P.; Singh, H.; Gurusinghe, S.; Mockler, J.C.; Lim, R.; Wallace, E.M. The effects of hydroxychloroquine on endothelial dysfunction. Pregnancy Hypertens. 2016, 6, 259-262. [CrossRef]

239. Gambardella, J.; Morelli, M.; Sardu, C.; Santulli, G. Targeting Endothelial Dysfunction in COVID-19. Nature 2020, in press.

240. Ciccarelli, M.; Santulli, G.; Campanile, A.; Galasso, G.; Cervero, P.; Altobelli, G.G.; Cimini, V.; Pastore, L.; Piscione, F.; Trimarco, B.; et al. Endothelial alpha1-adrenoceptors regulate neo-angiogenesis. Br. J. Pharmacol. 2008, 153, 936-946. [CrossRef]

241. Wilbert-Lampen, U.; Seliger, C.; Zilker, T.; Arendt, R.M. Cocaine increases the endothelial release of immunoreactive endothelin and its concentrations in human plasma and urine: Reversal by coincubation with sigma-receptor antagonists. Circulation 1998, 98, 385-390. [CrossRef] [PubMed]

242. Amer, M.S.; McKeown, L.; Tumova, S.; Liu, R.; Seymour, V.A.; Wilson, L.A.; Naylor, J.; Greenhalgh, K.; Hou, B.; Majeed, Y.; et al. Inhibition of endothelial cell $\mathrm{Ca}(2)(+)$ entry and transient receptor potential channels by Sigma-1 receptor ligands. Br. J. Pharmacol. 2013, 168, 1445-1455. [CrossRef] [PubMed]

243. Massamiri, T.; Duckles, S.P. Sigma receptor ligands inhibit rat tail artery contractile responses by multiple mechanisms. J. Pharmacol. Exp. Ther. 1991, 259, 22-29. [PubMed]

244. Hamidi Shishavan, M.; Henning, R.H.; van Buiten, A.; Goris, M.; Deelman, L.E.; Buikema, H. Metformin Improves Endothelial Function and Reduces Blood Pressure in Diabetic Spontaneously Hypertensive Rats Independent from Glycemia Control: Comparison to Vildagliptin. Sci. Rep. 2017, 7, 10975. [CrossRef] 
245. Bolz, S.S.; Pohl, U. Indomethacin enhances endothelial NO release-evidence for a role of PGI2 in the autocrine control of calcium-dependent autacoid production. Cardiovasc. Res. 1997, 36, 437-444. [CrossRef]

246. Sfikakis, P.P.; Papamichael, C.; Stamatelopoulos, K.S.; Tousoulis, D.; Fragiadaki, K.G.; Katsichti, P.; Stefanadis, C.; Mavrikakis, M. Improvement of vascular endothelial function using the oral endothelin receptor antagonist bosentan in patients with systemic sclerosis. Arthritis Rheum. 2007, 56, 1985-1993. [CrossRef]

247. Gupta, N.; Zhao, Y.Y.; Evans, C.E. The stimulation of thrombosis by hypoxia. Thromb. Res. 2019, 181, 77-83. [CrossRef]

248. Xu, Z.; Shi, L.; Wang, Y.; Zhang, J.; Huang, L.; Zhang, C.; Liu, S.; Zhao, P.; Liu, H.; Zhu, L.; et al. Pathological findings of COVID-19 associated with acute respiratory distress syndrome. Lancet Respir. Med. 2020, 8, 420-422. [CrossRef]

249. Paranjpe, I.; Fuster, V.; Lala, A.; Russak, A.; Glicksberg, B.S.; Levin, M.A.; Charney, A.W.; Narula, J.; Fayad, Z.A.; Bagiella, E.; et al. Association of Treatment Dose Anticoagulation with In-Hospital Survival Among Hospitalized Patients with COVID-19. J. Am. Coll. Cardiol. 2020. [CrossRef]

250. Basu, A.; Kanda, T.; Beyene, A.; Saito, K.; Meyer, K.; Ray, R. Sulfated homologues of heparin inhibit hepatitis C virus entry into mammalian cells. J. Virol. 2007, 81, 3933-3941. [CrossRef]

251. Lee, E.; Pavy, M.; Young, N.; Freeman, C.; Lobigs, M. Antiviral effect of the heparan sulfate mimetic, PI-88, against dengue and encephalitic flaviviruses. Antiviral. Res. 2006, 69, 31-38. [CrossRef] [PubMed]

252. Walker, S.J.; Pizzato, M.; Takeuchi, Y.; Devereux, S. Heparin binds to murine leukemia virus and inhibits Env-independent attachment and infection. J. Virol. 2002, 76, 6909-6918. [CrossRef] [PubMed]

253. Connell, B.J.; Lortat-Jacob, H. Human immunodeficiency virus and heparan sulfate: From attachment to entry inhibition. Front. Immunol. 2013, 4, 385. [CrossRef] [PubMed]

254. Nahmias, A.J.; Kibrick, S. Inhibitory effect of heparin on herpes simplex virus. J. Bacteriol. 1964, 87, $1060-1066$. [CrossRef]

(C) 2020 by the authors. Licensee MDPI, Basel, Switzerland. This article is an open access article distributed under the terms and conditions of the Creative Commons Attribution (CC BY) license (http://creativecommons.org/licenses/by/4.0/). 